\title{
Çin'in Güneybatı Sınırında Yapılan Uluslararası Evliliklerdeki “Vietnamlı Kadın” Üzerine Bir İnceleme
}

\section{A Study on the "Vietnamese Woman" in International Marriages on China's Southwest Border}

\author{
Liping $\mathrm{HU}^{(*)}$
}

\begin{abstract}
$\ddot{0} z$
Çin' in Reform ve Dışa Açılma politikasının ardından, sosyo-ekonomik düzeyin hızla gelişmesiyle birlikte Çin, göç veren bir ülkeden göç alan bir ülkeye dönüşmüştür. Son yıllarda, Çin'in güneybatı sinırında yaşayan halklar ile Vietnam'dan gelmiş kadınların birbirleriyle evlenmeleri günden güne artı̧ göstermektedir. Şehre giden göçmen Çinli kadın iş̧̧i sayısının artması, evlilik için ödenmesi gereken başlik parasının sürekli yükseltilmesi ve kursal toplumda sosyal evlilik çemberinin genişlemesi nedenleriyle Çin'in sinır bölgelerindeki cinsiyet oranında dengesizlik artmıştır. Benzer kültür ve yaşam alşkanlarına sahip olmaları, mevcut yaşam koşullarının iyileştirilmesi, ekonomik çıkar gibi sebeplerden dolayı Vietnamlı kadınlar yasadısı yollarla Çin'in güneybatı sinırlarında yaşayan Çinli erkeklerle evlenip Çin'de yaşamaktadırlar. Bu durum, Çin'in güneybatı sinırındaki bölgelerde bazı olumsuz sonuçlara yol açmaktadır. Bu makale, Çin'in güneybatı sinırında ulus ötesi evliliklerde bulunan Vietnamlı kadınlar üzerine Çin akademik çevresinde yapılmış araştırmaların incelenip değerlendirilmesine dayanmakta olup, bu sinır bölgelerindeki halkların Vietnamlı kadınlarla yaptı̆̆ evliliklerin toplumsal arka planın ve Vietnamlı kadınların yaşam durumların açıklamaktadır. Bunun yanısıra, sosyal yönetişim perspektifinden bu ulus ötesi evliliklerin sinır bölgelerindeki sosyal yönetişim üzerindeki etkisini tartışmayı ve iyi bir sınır evliliği mekanizmasın
\end{abstract}

\footnotetext{
Özgün Araştırma Makalesi (Original Research Article)

Geliş Tarihi: 15.04.2021 Kabul Tarihi: 25.10.2021

(*) Doktora Öğrencisi, Hacettepe Üniversitesi Sosyal Bilimler Enstitüsü Sosyoloji Bölümü

E-posta: lipinghu87@gmail.com

ORCID ID: https://orcid.org/0000-0002-6438-4539
}

Üsküdar

Üniversitesi

Sosyal Bilimler

Dergisi, 2021;

sayl: 13 ,

$333-374$ 


\section{Liping HU}

kurmak ve bu sinı ötesi evliliklerin neden olduğu sorunları çözmek için bazı hedefe yönelik karşı önlemler önermeyi amaçlamaktadır.

Anahtar Kelimeler: Çin-Vietnam, Çin'in Güneybatı Sinırındaki "Vietnamlı eşler," Uluslararası Evlilikler, Sosyal Sorunlar.

\section{Abstract}

With the policy of Reform and Opening and the rapid development of the socio-economic level, China has transformed from a migrant-sending country to an immigrant-receiving country. In recent years, intermarriages between men living on the southwestern border of China and women from Vietnam have increased. The increase of emigrating female workers from rural to urban areas, the ever-increasing

Üsküdar

University

Journal of Social

Sciences, 2021; issue: 13 , 333-374 bride prices and the expansion of the marriage circle in rural societies have increased the imbalance of gender ratio in the border areas of China. Vietnamese women get married with Chinese men through illegal means in southwestern China and then settle in China, because of factors such as similar cultural traditions and living habits, hopes for better living conditions, and economic interests. These intermarriages sometimes lead to negative effects in China's southwestern border. This article is based on the investigation and evaluation of researches that are from Chinese academic community on Vietnamese women in transnational marriages on the southwestern border of China. It aims to explain the social background of these international marriages, explore the influence of these transnational marriages on the social governance in border areas. It also aims to establish a good transnational marriage mechanism, discuss the problems caused by such transnational marriages, and try to put forward some targeted suggestions and measures from the perspective of social management.

Keywords: Sino-Vietnam, International Marriages, Social Issues, "Vietnamese Wives" in China's Southwestern Border.

\section{Giriş}

1960-1970'lerde Avrupa ve ABD gibi gelişmiş ülkelerde uluslararası evliliklerin ortaya çıkması, özellikle de 1970'lerde sipariş gelin (mailorder bride) olgusunun ortaya çıkmasıyla, bir evlilik modeli olarak, 


\section{Çin’in Güneybatı Sınırında Yapılan Uluslararası Evliliklerdeki "Vietnamlı Kadın"}

uluslararası evlilik insanların görüş alanı içerisine dahil olmuştur. ${ }^{1}$ Aynı zamanda küreselleşmenin de hızlanmasıyla, dünya çarpında çoğu ülkede uluslararası evlilik yıldan yıla artmakta ve yaygınlaşmaktadır. ${ }^{2}$ Dünya

${ }^{1}$ Price, C. A. \& Zubrzycki, J. The use of inter-marriage statistics as an index of assimilation, Population Studies 16, no.1 (1962): 58-69, https://doi.org/10.1080/00324728.1962 .10416769; Tapales, Proserpina Domingo. Women, Migration, and the Mail-Order Bride Phenomenon: Focus on Australia, Philippine Journal of Public Administration 34, no. 4 (1990): 311-322, https://pssc.org.ph/wp-content/pssc-archives/Philippine\%20 Journal\%20of\%20Public\%20Administration/1990/Num\%204/07_Women_\%20 Migration\%20and\%20the\%20Mail-Order\%20Bride.pdf; Cottrell, Ann Baker. Cross National Marriages: A Review of the Literature, Journal of Comparative Family Studies 21, no. 2 (Summer 1990): 151-169, https://doi.org/10.3138/jcfs.21.2.151(https:// www.jstor.org/stable/41602075); Appadurai, Arjun. 'Global ethnoscapes: notes and queries for a transnational anthropology', in R. G. Fox (ed.) Recapturing anthropology: working in the present, Santa Fe: School of American Research Press, (1991): 191210, https://eclass.aegean.gr/modules/document/file.php/SA200/Appadurai\%20 1991.pdf; Lloyd, Kathryn A. Wives for Sale: The Modern International Mail Order Bride Industry, Northwestern Journal of International Law \& Business 20, no. 2 (Winter 2000): 341-368, https://scholarlycommons.law.northwestern.edu/cgi/viewcontent. cgi article $=1512 \&$ context=njilb; Constable, Nicole. Romance on the Global Stage: Virtual Ethnography, Pen Pals and Mail Order Marriages. California: University of California Press, 2003; Rosario, Teresita C.Del. Bridal Diaspora: Migration And Marriage Among Filipino Women, Indian Journal Of Gender Studies, no.12, (2005): 253-273. https://doi. org/10.1177/097152150501200205.

${ }^{2}$ Piper, Nicola. International Marriage in Japan: 'Race' and 'Gender' Perspectives, Gender, Place and Culture 4, no. 3 (1997): 321-338, https://doi.org/10.1080/09663699725378; So, Alvin Y. Cross-Border Families in Hong Kong: The Role of Social Class and Politics, Critical Asian Studies 35, No.4 (2003) :515-534, https://doi.org/10.1080/146727103200014701 4; Suzuki, Nobue. Inside the Home: Power and Negotiation in Filipina Japanese Marriages, Women's Studies 33, No.4 (2004): 481-506, https://doi.org/10.1080/00497870490445027; Lee, Yean -Ju \& Seol, Dong -Hoon \& Cho, Sung -Nam, International Marriages In South Korea: The Significance of Nationality And Ethnicity, Journal of Population Research 23, No. 2 (2006): 165-182; https://link.springer.com/content/pdf/10.1007/BF03031814.pdf; Davin, Delia. Marriage Migration in China and East Asia, Journal of Contemporary China 16, No.50 (2007): 83-95, https://doi.org/10.1080/10670560601026827; Wang, Hongzen. Hidden Spaces of Resistance of the Subordinated: Case Studies from Vietnamese 


\section{Liping HU}

üzerinde yaşanan uluslararası evlilikler, Çin'de uluslararası evliliklerin artmasını de etkilemiş ve Çin, yabancı kadınların uluslararası evlilikler yoluyla göç ettikleri önemli bir göç ülkesi hâline gelmiştir.

Son otuz-kırkyılda, Çin'deyaşanan "Reformve DışaAçılma” politikasıve onu takip eden hızlı ekonomik ve sosyal kalkınmayla birlikte Çin, göç veren bir ülkeden göç alan bir ülkeye dönüşmüştür. Özellikle 1990’lardan sonra, Çin'in bu hızlı sosyo-ekonomik gelişimi, sınır komşularıyla dostluğunun gelişmesi ve ilişkilerin artmasıyla birlikte, Çin toplumunda çok sayıda uluslararası evlilik ortaya çıkmış ve bu evlilikler her geçen yıl daha da artış göstermektedir. Bu uluslararası evlilikler özellikle sınır bölgelerinde daha şiddetli bir artış göstermektedir. Aslında, Çin sınırlarındaki uluslararası

Üsküdar

University

Journal of Social

Sciences, 2021; issue: 13 , 333-374 evlilikler yeni bir olgu sayılmaz. Zira Çin'in güneybatısı ve Vietnam, Myanmar, Laos gibi ülkelerin birbirileriyle binlerce kilometre sınır hattı bulunduğu için bu sınırda yaşayan çok sayıda sınır ötesi etnik grup vardır. ${ }^{3} \mathrm{Bu}$ sınır ötesi etnik gruplar, aralarındaki benzer tarihsel kökenler,

Female Migrant Partners in Taiwan, İnternational Migration Review 41, No.3 (2007): 706727, https://doi.org/10.1111/j.1747-7379.2007.00091.x; Lee, Hye-Kyung. International Marriageand the State in South Korea: Focusingon Governmental Policy, Citizenship Studies 12, No.1 (2008): 107-123. https://doi.org/10.1080/13621020701794240; Tan, Eugene K.B. A union of gender equality and pragmatic patriarchy: international marriages and citizenship laws in Singapore, Citizenship Studies 12, No. 1 (2008): 73-89. https://doi. org/10.1080/13621020701794190; Niedomysl, Thomas \& Östh, John \& Ham, Maarten van. The Globalisation of Marriage Fields: The Swedish Case, Journal of Ethnic and Migration Studies 36, no.7 (2010): 1119-1138, https://doi.org/10.1080/13691830903488184; Shipper, Apichai W. Introduction: Politics of Citizenship and Transnational Gendered Migration in East and Southeast Asia, Pacific Affairs 83, no. 1 (Spring 2010): 11-29. https:// dornsife.usc.edu/assets/sites/731/docs/Politics_of_Citizenship.pdf; Seah, Mabel. 'The Family' As An Analytıcal Tool: Cases From International Marriages And Marriage Migration İn East Asia, International Journal Of Sociology Of The Family 38, no. 1 (2012): 63-84, https://www.jstor.org/stable/43488390?seq=1\#metadata_info_tacontents.

${ }^{3}$ Sınır ötesi etnik grup, iki ya da daha fazla ülkenin sınırı arasında yaşayan aynı etnik grupları ifade eder. Sını ötesi etnik grup, tarihte oluşturulmuş ancak günümüzde iki veya daha fazla ülkede dağıtılan ve ilgili ülkelerin sınırında birbirine bitişik olarak yaşayan aynı etnik gruba 


\section{Çin’in Güneybatı Sınırında Yapılan Uluslararası Evliliklerdeki "Vietnamlı Kadın"}

kültürel geçmişler ve yaşam gelenekleri nedeniyle, sürekli sınır ötesi evlilik geleneğine sahip olmuşlardır. Aynı zamanda bir süredir Çin'de aile planlamasına yönelik politikaların uygulanması ve erkek çocukların kız çocuklarına göre daha çok tercih edildiği bir geleneksel toplumsal düzen bulunması nedeniyle günümüz Çin toplumunda görülen bu durum, cinsiyet oranında ciddi bir dengesizlik meydana getirmiştir. Ayrıca, son yıllarda Çin'de bazı kırsal bölgelerde kızlar için istenen başlık parasının yüksek miktarlarda olduğu görülmektedir. Çin'in kırsal bölgelerinde, özellikle Çin'in güneybatısında yer alan kırsal bölgelerde yaşayan yoksul erkekler, istenen başlık parasını karşılayamadıkları için Vietnam, Myanmar gibi ülkelerden gelen kadınlarla evlenmeye yönelmektedirler. ${ }^{4}$ $\mathrm{Bu}$ bağlamda, Çin'in güneybatı sınırında yaşayan halklarda erkeklerin Vietnam, Myanmar, Laos gibi komşu ülkelerin sınırında yaşayan kadınlarla evlenmeleri çok yaygınlaşmıştır.

Çin sınırında yaşayan yabancı eşlerin arasında en çok Vietnamlı kadınlar bulunmaktadır. Bazı kesin olmayan istatistiklere göre, Çin'de yaşayan Vietnamlı eşlerin toplam sayısının 100.000 kişiyi aştığı tahmin

grubu ifade eder. Aslında, sınır ötesi etnik grup, toprakların farklı ülkelerin siyasi güçlerin tarafından bölünmesinin bir sonucudur. Onlar aynı veya benzer dil, aynı yaşam tarzı ve kültürel gelenekler gibi ortak veya benzer milli kültürel özelliklere sahipler, birbiriyle aynı veya benzer etnik grup algılayışı bile vardır.

${ }^{4}$ Dai, Bo ve Zhao, Deguang 戴波, 赵德光, “Zhongmian, Zhonglao, Zhongyue Shaoshu Minzu Kuajing Hunyin Xingwei de Jingjixue Sikao, 中缅、中老、中越少数民族跨境 婚姻行为的经济学思考, Shijie Minzu世界民族, say1: 2, (2016): 54-65, https://t.cnki. net/kcms/detail?v=3uoqIhG8C46NmWw7YpEsKMypi3qVj28L ntHptynnzpiPCHBHX hEuVbMJRGgNKRVeup5_73WebypxdBAPJQ2yZbNCZD6isJ-d\&uniplatform=NZKPT; Lei, Guangming雷光明, Wang, Baotong王保同, “Woguo Bianmin Kuajing Hunyin Jiating de Kunhuo Yu Sikao---Yi Yunnan、Guangxi Bianjing Diqu Weili我国边民跨境 婚姻家庭的困境与思考---以云南、广西边境地区为例," Zhongyang Minzu Daxue Xuebao(Zhexue Shehui Kexueban)中央民族大学学报(哲学社会科学版) 43, say1: 2, (2016): 72-78, https://doi.org/10.15970/j.cnki.1005-8575.2016.02.010. 


\section{Liping HU}

edilmektedir. ${ }^{5}$ Çin ve Vietnam birbirine komşu iki ülke olmasından dolayı Çin ve Vietnam arasında uluslararası evlilikler eskiden beri sürekli yaşanmaktadır. 1991 yılında Çin-Vietnam ilişkilerinin normalleşmesiyle bu iki ülke arasında uluslararası evliliklerin sayısı yıldan yıla artmıştır. ${ }^{6}$ Özellikle 21. yüzyılın başlarından itibaren, Vietnamlı kadınlar akın akın Çin’e gelip Çinli erkeklerle evlenmeye başlamış ve böylece Çin sınırında Vietnamlı eşlerin sayısının artmasıyla, bu uluslararası evlilikler giderek araştırmacıların daha fazla dikkatini çeker hale gelmiştir.

Çin sınırında yaşanan Çin-Vietnam uluslararası evlilikleri, araştırmacılar tarafından doğrudan yapılan görüşmeler ve anketler yoluyla farklı

Üsküdar University Journal of Social Sciences, 2021; issue: 13 , 333-374 perspektiflerdenbilimselolaraktartışılmışolup birçokaraştırmanın konusu olmuştur. Çin’deki akademik çevrelerce kullanılan "Baidu Akademik" adlı web sitesinde konuyla ilgili taramayapıldığında, 2000 yılından beribukonu hakkında yapılmış olan toplamda 215 araştırma olduğu ve bunların içinde direkt "Çin-Vietnam sınırında ulus ötesi evlilik" meselesini konu alan 90

${ }^{5}$ Luo, Wenqing 罗文青, “Yazhou Hunyin Yimin Shijiaoxia de Zhongyue Kuaguo Hunyin Wenti Yanjiu亚洲婚姻移民视角下的中越跨国婚姻问题研究,” Changjiang Shifan Xueyuan Xuebao长江师范学院学报 29, say1: 3, (2013): 1-6, https://xuewen.cnki.net/ CJFD-FLSZ201303002.html; Liu, Jifeng刘计峰, “Zhongyue Bianjing Kuaguo Hunyin Yanjiu Shuping 中越边境跨国婚姻研究述评, Xibei Renkou西北人口32, say1: 6, (2011): 64-68, https://doi.org/10.15884/j.cnki.issn.1007-0672.2011.06.018.

${ }^{6}$ Wang, Xiaodan 王晓丹, “Zhongyue Bianjing Kuaguo Hunyin de Dongji he Shehui Yingxiang---Yi Yunnansheng Malipoxian Weili中越边境跨国婚姻的动机和社会影 响——以云南省麻栗坡县为例, ”Yunnan Shifan Daxue Xuebao (Zhexue Shehui Kexueban) 云南师范大学学报 (哲学社会科学版) 43, no. 1, (2011): 117-120, https://t.cnki.net/kcms/detail?v=3uoqIhG8C46NmWw7YpEsKL-WhGHP2RH EsfUP 6uypmiObOkRmQOtSO0tj4NoqTL6Uzk5q0qZ_ipv9AJUgZ9GGS9Z̄PH3L6Mz\&uniplatform=NZKPT; Jones, Gavin and Shen, Hsiu-hua, International Marriage In East And Southeast Asia: Trends And Research Emphases. Citizenship Studies 12, no. 1, (2008, February): 9-25. https://doi.org/10.1080/13621020701794091 


\section{Çin’in Güneybatı Sınırında Yapılan Uluslararası Evliliklerdeki "Vietnamlı Kadın"}

sonuç yer aldığı tespit edilmiştir. Ancak "Baidu akademik” yüksek lisans ve doktora derecelerindeki yayınlanmamış tezleri içermediğinden, $\mathrm{CNKI}$ (Çin Ulusal Bilgi Altyapısı) ${ }^{8}$ adlı bir diğer akademik platformda da tarama yapılmış ve neticede konuyla ilgili olan toplam 26 tez bulunmakta olduğu ve 13 tezin direkt olarak bu konuyu ele aldığı görülmüştür. Bu araştırmalar göstermektedir ki; Vietnamlı kadınlar genelde arkadaşları ve akrabaları ${ }^{9}$

${ }^{7}$ Baidu Akademik, Haziran 2014’te Çin merkezli Baidu şirketi tarafından kurulmuş, çok
sayıda Çince ve İngilizce kaynak içeren, literatür taramaları için kullanılan bir akademik
platformdur. Buradaki akademik kaynaklar her türlü akademik dergiyi, konferans
makalelerini ve gazeteleri kapsar. (https://baike.baidu.com/item/\%E7\%99\%BE\%E5\%
BA\%A6\%E5\%AD\%A6\%E6\% 9C\%AF\%E6\% 90\%9C\%E7\%B4\%A2/5310267,
erişim 5 Aralık 2020). CNKI; Çince: 中国知网, Pinyin transkribsiyon: Zhongguo zhiwang), 1999 yılında Çin’in en prestijli üniversitelerinin başında gelen Tsinghua Üniversitesi tarafından kurulmuştur. CNKI, Çin akademik çevrelerinde bilginin üretimi, yayılması ve kullanılması yoluyla geniş bir bilgi veritabanı inşa etmeyi ve bilgiyi dijital yollardan toplumun tüm

Üsküdar

Üniversitesi

Sosyal Bilimler

Dergisi, 2021;

sayl: 13 ,

$333-374$ kesimine yaymayı amaçlamaktadır. CNKI veritabanında dergileri, yüksek lisans ve doktora tezlerini, konferans makalelerini, gazeteleri, referans kitaplarını, yıllıkları, patentleri ve standartları barındırmaktadır. Yani CNKI, yerel ve küresel literatürü birleştiren bir dijital akademik platform olarak düşünülebilir. CNKI web sitesinde günlük olarak güncellenen 50.000'den fazla makale bulunmaktadır. https://baike.baidu.com/ item/\%E4\%B8\%AD\%E5\%9B\%BD\%E7\%9F\%A5\%E7\%BD\%91/ 1316830 erişim 4 Kasım 2021.

${ }^{9}$ Man, Liping 满丽萍, “Yimin Shehuixue Shiyexiao de Dianyue Bianjing Feifa Kuaguo Hunyin Yinmin Wenti移民社会学视野下的滇越边境非法跨国婚姻移民问 题, Honghe Xueyuan Xuebao 红河学院学报 10, say1: 1, (2012): 19-23. https://doi. org/10.13963/j.cnki.hhuxb.2012.01.026; Chen, Xun 陈讯, “Ziyuan Hubu, Hunsu Leitong Yu Jiegouxing Liliang Baohuxia de Zhongyue Bianjing Kuaguo Hunyin Yanjiu--Yi Guangxi Chongzuoshi G'cun Weili 资源互补、婚俗类同与结构性力量保护下 的中越边境跨国婚姻研究---以广西崇左市 G 村为例, Y Yunnan Xingzheng Xueyuan Xuebao云南行政学院学报 19, say1: 4, (2017): 5-11, https://doi.org/10.16273/j. cnki.53-1134/d.2017.04.001. 


\section{Liping HU}

veya evlilik ajansları ${ }^{10}$ gibi yollarla Çin'in güneybatı sınırlarında yaşayan Çinli erkeklerle tanışıp evlenmişlerdir. Ancak, çoğu Vietnamlı eş resmi nikah olmadan Çinli erkeklerle evlenmiş, bazıları ekonomik yoksulluk nedeniyle kendi ülkelerinden kimlik belgelerini alabilmeleri için yüksek ücretler ödeyememelerinden, bazıları ise prosedürlerin karmaşıklı̆̆ından veya nasıl başvuru yapılacağını bilmediklerinden dolayı kimlik belgelerini alamamışlardır." Dolayısıyla, bu Vietnamlı kadınlar Çin’e girdikten sonra Çinli erkekler ile bir düğün yaparak fiili evlilik yapabilseler de, yasal kimlik belgelerine sahip olmadıkları için resmi nikahla evlenememişler ve böylece bu evlilikler yasal statüye sahip olmamıştır. Bu demektir ki Çin'in güney sınırında yaşayan Vietnamlı kadınların birçoğu illegal olarak Çinli erkekler ile evlenerek Çin’de yasadışı olarak yaşamaktadır. Böyle bir

Üsküdar

University

Journal

of Social

Sciences, 2021;

issue: 13 ,

333-374 durum altında yaşayan bu Vietnamlı kadınlar iyi sayılamayacak yaşam koşullarına sahiptir.

Hatta çoğu Vietnamlı kadının bir grup "vatandaş olmayan kadın” haline geldiği söylenebilmektedir ve Çin’de siyasi kimlikleri olmayan marjinal insanlar olarak yaşamaktadırlar. Aynı zamanda sınırlarda meydana gelen bu uluslararası evlilikler, Çin'in güneybatı sınırındaki

${ }^{10}$ Luo, Wenqing罗文青, “Yazhou Hunyin Yimin Shijiaoxia de Zhongyue Kuaguo Hunyin Wenti Yanjiu亚洲婚姻移民视角下的中越跨国婚姻问题研究”, Changjiang Shifan Xueyuan Xuebao长江师范学院学报 29, sayı: 3, (2013): 1-6, https://xuewen.cnki.net/ CJFD-FLSZ201303002.html.

${ }^{11} \mathrm{Lu}$, Haifa 陆海发, “Bianjing Kuaguo Hunyin Yimin Zhili: Tiaozhanyu Pojie Zhidao 边境跨国婚姻移民治理: 挑战与破解之道, X Xinan Minzu Daxue Xuebao(Renwen Shehui Kexueban) 西南民族大学学报(人文社会科学版) 37, say1: 3, (2016): 48-53, https://kns.cnki. KCMS/detail/detail.aspx?dbcode=CJFQ \&dbname=CJFDLAST2016\& filename $=X N Z S 201603009 \& v=$ MDQ2OTBmTXJJOUZiWVI4ZVgxTHV4WVM3RGg xVDNxVHJXTTFGckNVUjd1Zll1UnZGeTdtVUwvTVBTUFJmYkc0SDk=

${ }^{12} \mathrm{Li}$, Juan李娟, Luo, Liuning罗柳宁, Long, Yao 龙耀, “Renleixue Shiyezhong de “Wuguoji Nüren”---Yi Guangxi Daxingxian A'cunWeili 人类学视野中的”无国籍女人”---以广 西大新县A村为例," Baise Xueyuan Xuebao 百色学院学报 20, say1: 1, (2007): 7-14, https://doi.org/10.16726/j.cnki.bsxb.2007.01.002. 


\section{Çin’in Güneybatı Sınırında Yapılan Uluslararası Evliliklerdeki "Vietnamlı Kadın"}

bölgelerde yaşayan ailelerin istikrarsızlığı, bu uluslararası ailelerde yaşayan çocuklar için iyi olmayan eğitim koşulları, sosyal güvenlik sorunları, kamu düzenine ve istikrarına yönelik açık veya gizli tehlikeler dahil olmak üzere bazı olumsuz etkiler de yaratmaktadır.

Yukarıda bahsedilen bilgilerin ışı̆̆ında, bu çalışma için "Baidu akademik” ve CNKI'da Çin'in güneybatı sınırında ulus ötesi evliliklerde bulunan Vietnamlı kadınlar üzerine yapılmış araştırmalar tespit edilmiş ve incelenmiştir. Dolayısıyla bu çalışma, temel bilgi kaynağını mevcut literatürden almakta olup, "sosyal yönetişim" perspektifiyle bu tür ulus ötesi evliliklerinin sosyal arka planını ve bunların sınır bölgelerindeki etkisini tartışmaktadır. Böylece sınır ötesi evliliklerin yaratmış olduğu sorunlara yönelik bazı çözüm önerileri üreterek daha iyi bir evlilik mekanizması kurulmasına katkıda bulunmayı amaçlamaktadır. Zira sınır ötesi evliliklerin normalleşmesi, sınır bölgelerinin istikrarına ve sınırda yaşayan toplumda uyumlu bir sosyal düzenin inşasına katkıda bulunmaktadır.

Dünya çarpında uluslararası evliliklerin artması ve yaygınlaşmasıyla birlikte Türkiye'deki uluslararası evlilikler de yıldan yıla artan bir eğilim göstermektedir ve bu bağlamda Türkiye'de bulunan uluslararası evlilik olgusu araştırmacıların odak noktalarından biri haline gelmiştir. Bununla birlikte, Türk akademik çevrelerinde uluslararası evlilikler üzerine mevcut araştırmalar, esas olarak uluslararası evliliklerin yapıldığı nedenler veya motivasyonlar ${ }^{13}$ ve uluslararası evlilik yapanların Türkiye'deki

\footnotetext{
${ }^{13}$ Deniz, Ayla ve Özgür, E. Murat. “Antalya'daki Rus gelinler: Göçten evliliğe, evlilikten göçe," Sosyoloji Dergisi, 3, no. 27, (2013): 151-175. https://dergipark.org.tr/tr/pub/ iusosyoloji/issue/540/5009; Altun, Nurullah Ve Dinç, Aybike, "Yabancı Gelinlerin Türk Ailesi İçindeki Yerine Sosyolojik Bir Bakış(pdf.),” Mart 25-27, Halk Kültüründe Aile Uluslararası Sempozyumu, (2016). https://www.academia.edu/25173459/; Erkeç, Ulviya Filiyeva. "Evlilik Yoluyla Kadın Göçü ve Türkiye’de "Rus Gelin”lerin Durumu," Sosyal ve Beşeri Bilimler Dergisi, 1, no. 2, (2017): 21- 43. https://dergipark.org.tr/tr/pub/ jssh/issue/35726/393283; Gökmen, Çisel Ekiz. “Türk Turizminin Yabancı Gelinleri:
}

Üsküdar

Üniversitesi

Sosyal Bilimler Dergisi, 2021;

sayl: 13 , $333-374$ 


\section{Liping HU}

hayatlarında karşılaştıkları sorunlar ${ }^{14}$ ve evlilikten memnuniyetleri ${ }^{15}$ üzerinde yoğunlaşmıştır. Ancak, uluslararası evliliklerin ve uluslararası evlilik yapanların topluluğun veya toplumun yönetişimi perspektifinden Türk toplumu üzerindeki etkisine dair yapılmış araştırma çok azdır. Bu araştırma, Çin'in güneybatı sınır bölgesinde bulunanuluslararası evliliklerle ilgili literatürün değerlendirilmesiyle, Türk akademik çevresinin Çin'in sınırında bulunan uluslararası evlilikler hakkında nispeten kapsamlı bir anlayışa sahip olmasına yardımcı olarak, Türk uluslararası evlilik olgusuna yönelik yeni araştırma perspektifleri sunup, ulus ötesi evlilikler üzerine araştırma içeriğini zenginleştirebilir.

\section{1. Çin'in Güneybatı Sınırındaki Vietnamlı Eşlerin Sosyal Arka Planı}

Üsküdar

University

Journal of Social

Sciences, 2021; issue: 13 , 333-374

Çin sınırlarındakiuluslararası evliliklere dair literatür incelendiğinde, bu tür uluslararası evliliklerin dağılımının çoğunlukla Çin'in güneybatısında olduğu görülmektedir. Çin'in güneybatısının, Laos, Myanmar ve Vietnam ile sınırı bulunmaktadır. Vietnam ile Çin'in Yunnan ve Guangxi bölgeleri birbirine bitişiktir ve aradaki sınırın toplam uzunluğu 2.449 kilometredir. Yunnan bölgesiyle Vietnam arasında 1.339 kilometrelik ve Guangxi

Marmaris Yöresinde Turizm Sektöründe Çalışan Göçmen Kadınlar," Çalışma ve Toplum, no. 1, (2011):201-232. https://www.calismatoplum.org/Content/pdf/ calisma-toplum1354-d767667b.pdf; Pusch, Barbara, "Karşı İstikametten Göç: Türkiye’deki Yüksek Vasıflı Alman Kadınlar," Sosyoloji Dergisi 3, no. 27/2, (2013): 123-149. https://dergipark.org. $\mathrm{tr} / \mathrm{tr} / \mathrm{pub} /$ iusosyoloji /issue/540/5008; Adiloğlu, Selda. "Kosovalı Kadın Göçmenler ve Sosyal Motivasyonları,” Uluslararası Toplum Araştırmaları Dergisi 8, no. 15, (2018): 830-857.https://doi.org/ 10.26466/opus.413256.

${ }^{14}$ Yıldırım, Ayşe, “Sınır-ötesi Evlilikler ve Sınır Çokkarılılığı: «İthal Kumalar»," Antropoloji, no. 29, (2015):131-162. https://doi.org/10.1501/antro_0000000315; Deniz, Ayla ve Özgür, E. Murat, 151-175; Altun, Nurullah ve Dinç, Aybike.

${ }^{15}$ Nakipbayeva, Zhanar. Umutların ve Hayal Kırıklıkların Sosyo-Kültürel Arka Planı: Türk Erkekleriyle Evlenen Kazakistanlı Kadınların Evlilik Memnuniyeti Üzerine Nitel Bir Çalışma (Yayınlanmamış Doktora Tezi), Ankara: Hacettepe Üniversitesi Sosyal Bilimler Enstitüsü, 2020. 


\section{Çin’in Güneybatı Sınırında Yapılan Uluslararası Evliliklerdeki "Vietnamlı Kadın"}

bölgesiyle Vietnam arasında da 1.050 kilometrelik sınır bulunmaktadır. $\mathrm{Bu}$ iki binden daha fazla kilometrelik Çin-Vietnam sınırında Zhuang, Jing ve Miao gibi 20'den daha fazla sınır ötesi etnik grup yaşamaktadır. Buralarda yaşayan sınır ötesi etnik grupların halkları arasında sınır ötesindeki etnik ilişkilerdeki yakınlık ve ekonomik, siyasi ve toplumsal birçok faktörün de etkisiyle, uluslararası evliliklerinin uzun bir geçmişi bulunmaktadır. Bu nedenle, bu uluslararası evliliklerin Çin-Vietnam sınır bölgelerindeki yaşayan halkların kültürel miras yakınlığına dayanmakta olduğu söylenebilir. Bu konunun tarihçesine baktığımızda, 1949'dan önce, Çin hükümetinin toplumsal anlamda sınır yönetimi sıkı olmadığı için Çin sınırındaki ülkelerin vatandaşlarıyla yapılan evlilikler çok serbest ve denetimsiz haldeydi. ${ }^{16} 1980$ 'lerden itibaren, Çin ve Vietnam'ın art arda Reform ve Dışa Açılma politikası uygulamasının ardından 1990'lardan itibaren Çin ve Vietnam arasındaki ilişkilerin gitgide iyileştirilmesiyle ve Çin ve Vietnam'daki etnik gruplar arasındaki temasların artmasıyla, sınır bölgelerinde yaşanan uluslararası evliliklerin sayısı da artmıştır. ${ }^{17}$ Yapılan çok sayıda araştırmaya göre, Çin'in güneybatı sınırındaki Vietnamlı kadınlarla yapılan evliliklerin, temel olarak, geleneksel etnik kültürler ve yaşam alışkanlıklarından, Çin ve Vietnam arasındaki ekonomik kalkınma farklılıklarından, Çin ve Vietnam arasındaki nüfusun cinsiyet oranlarının dengesizliklerinden kaynaklandığı düşünülmektedir.

İlk olarak, geleneksel etnik kültürler ve benzeri yaşam alışkanlıkları ÇinVietnam sınırındaki uluslararası evlilikler için kültürel temel sağlamaktadır. Eski zamanlardan beri, Çin sınır bölgelerinde yaşayan halkların sınırı olduğu komşu ülkeyle evlilik yapma geleneği bulunmaktadır. Daha önce

\footnotetext{
${ }^{16}$ Luo, Liuning 罗柳宁, Long, Yao 龙耀, “Zhongyue Bianjing Kuaguo Hunyin de Liubian Jiqi Sikao中越边境跨国婚姻的流变及其思考, ”Baise Xueyuan Xuebao百色学院学报 20, say1: 1, (2007): 15-21, https://doi.org/10.16726/j.cnki.bsxb.2007.01.003.

${ }^{17}$ Çin'in Reformu ve Dışa Açılma programı 1978'de başlamış olup, 1980’lerden bu yana sürekli uygulanmaktadır. Vietnam toplumunun ıslahatı ise 1986'da başlamıştır.
}

Üsküdar

Üniversitesi

Sosyal Bilimler Dergisi, 2021;

sayl: 13 , $333-374$ 


\section{Liping HU}

belirtildiği gibi, Çin-Vietnam sınırındaki Yunnan ve Guangxi bölgelerinde Zhuang, Jing, Miao, Yi, Yao ve Hani gibi sınırda yaşayan etnik gruplar bulunmaktadır. Çin-Vietnam sınırındaki sınır ötesi etnik grupların halkları, ülke sınırları nedeniyle farklı ülkelerde yaşamalarına rağmen, geçmişten beri birbirleriyle çok yakın temas halinde olup, sıklıkla nüfus hareketleri sürecinde aynı veya benzer etnik dilleri kullanmaktadırlar. Ayrıca, Çin-Vietnam sınırındaki halklar arasında gelenek, tarımsal üretim, yaşam tarzı, aile ahlakı, konut biçimleri, yeme alışkanlıkları, geleneksel kostümler, cenaze törenleri, halk inanışları, evlilik gelenekleri ve ritüelleri gibi birçok alanda ortaklık ve benzerlikler bulunmaktadır. ${ }^{18}$ Aynı zamanda,

Üsküdar

University

Journal of Social

Sciences, 2021; issue: 13 , 333-374 bu etnik gruplar sınırlarla birbirinden ayrılsalar ve farklı isimlerle anılsalar da bu gruplar arasında kan bağı kesilmemiş ve hâlâ belli bir etnik kimlik algısı bulunmaktadır. ${ }^{19}$ Bu bağlamda, bu sınır ötesi etnik gruplar çok yakın etnik ve kültürel bağlara sahip oldukları için benzer kültürel kimliklere sahip olmakta ve kolayca birbirini kabul edebilmektedir. Özellikle Çin'in güneybatı sınırında uluslararası evlilikler yapan Vietnamlı eşler için böyle bir evlilik yapmak, tanıdık bir kültürel çevreye girmelerini ve yabancılık

${ }^{18}$ Luo, Wenqing 罗文青, “Heping Yu Jiaowang: Guangxi Bianjing Diqu Kuaguo Hunyin Wenti Chutan 和平与交往: 广西边境地区跨国婚姻问题初探,” Guangxi Shifan Daxue Xuebao (Zhexue Shehui Kexueban) 广西师范大学学报(哲学社会科学版) 42, say1: 1, (2006): 52-56, https://kns.cnki.net/KCMS/detail/detail. aspx?dbcode= CJFQ\&dbname $=$ CJFD2006\&filename $=$ GXSS200601013\&v $=$ MTcyNzh6S0lqWFlmY kc0SHR mTXJvOUVaNFI4ZVgxTHV4WVM3RGgx VDNxVHJXTTFGck NVUjd1 Zll1UnZGeXpsVjc $=$

${ }^{19}$ Luo, Liuning 罗柳宁, “Lilun Zhongyue Bianjing Kuaguo Hunyin Jianli de Jichu--Jianlun “Wuguoji Nüren” De Shenfen 例论中越边境跨国婚姻建立的基础-----兼论“ 无国籍女人”的身份,”Guangxi Minzu Yanjiu广西民族研究, say1: 5, (2010): 57-61, https://kns.cnki.net/KCMS/detail/detail.aspx? dbcode=CJFQ\&dbname =CJFD2010 \&filename $=$ MZYA201001015\&v=MjA3NDZ1Zl11UnZGeXptVXI3S0tEZINiN0c0SD IITXJvOUVZWVI4ZVgxTHV4WVM3RGgxVDNxVHJXTTFGckNVUjc=. 


\section{Çin’in Güneybatı Sınırında Yapılan Uluslararası Evliliklerdeki "Vietnamlı Kadın"}

çekmemelerini sağlamaktadır. ${ }^{20}$ Ayrıca, aynı veya benzer etnik dilleri kullandıkları için bu Vietnamlı eşler ve aile üyeleri arasında iletişimin önünde büyük bir engel yoktur. Dolayısıyla, onlar Çin'in güneybatı sınırlarında yaşayan insanlarla evlendikten sonra başarılı bir şekilde yerel yaşam ile bütünleşip sınır etnik kültürüne uyum sağlayabilmektedirler. $\mathrm{Bu}$ temel dinamik onların kültür şokunu azaltmakta ve yeni yaşam ortamına uyum sağlamalarını kolaylaştırmaktadır. $\mathrm{Bu}$ nedenle, benzer kültürel gelenekler, yalnızca Çin’in güneybatı sınırında uluslararası evliliğin bir temeli değil, aynı zamanda evliliğin sürdürülmesinde de temel bir unsurdur.

İkinci olarak, Çin ve Vietnam arasındaki ekonomik gelişme farkı, Vietnamlı kadınların bu uluslararası evlilikleri yapmasının gerçekçi nedenidir. Özellikle Çin'de Reform ve Açılım programının uygulanması, XXI. yüzyılın başından itibaren Çin hükümetinin güneybatı sınırındaki azınlık bölgelerinde uygulanan "Sınırlardaki Sosyo-ekonomiyi İyileştirme ve İnsanları Zenginleştirme Eylemi” adlı projeyle birlikte yeni bir sosyalist kırsal bölgenin inşası gibi önemli stratejik girişimlerin ve destekleyici politikaların uygulanması ile Guangxi, Yunnan vb. Çin'in güneybatı sınırındaki birçok şehir ekonomik açıdan kalkınmıştır. ${ }^{21}$ $\mathrm{Bu}$ temelde, altyapının onarımı sayesinde, eskiden tıkanan trafik

\footnotetext{
${ }^{20}$ Tao, Zixiang 陶自祥, “Zhongyue Bianjing Kuaguo Hunyin Chansheng de Shehui Jichu--Yi Guangxi Longzhouxian C'cun Weili 中越边境跨国婚姻产生的社会基础---以广 西龙州县G村为例, Renkou Yu Shehui人口与社会 33, say1: 3, (2017): 90-103, doil0. 14132/j.2095-7963.2017.03.011.

21 “Sınırlardaki Sosyo-ekonomiyi İyileştirme ve İnsanları Zenginleştirme Eylemi” (“Xingbian Fuming Xingdong 兴边富民行动”), Çin Ulusal Sivil İşler Komisyonu, Ulusal Kalkınma ve Reform Komisyonu ve Maliye Bakanlığı tarafından 1999 yılında başlatılan bir sınır inşaatı projesiydi. Bu eylemin amacı, sınırların yeniden canlandırılması ve sınır insanlarının zenginleştirilmesidir, güncelleme 27 Ocak 2021, erişim 27 Kasım 2010, https://baike.baidu.com/item/\%E5\%85\%B4\%E8\%BE\%B9\%E5\%AF\%8C\%E6\%B0\%9 1\%E8\%A1\%8C\%E5\%8A\%A8/9386311.
}

Üsküdar

Üniversitesi

Sosyal Bilimler Dergisi, 2021;

sayı: 13 , $333-374$ 


\section{Liping HU}

büyük ölçüde gelişmiştir. Çin'deki kırsal bölgelerde sağlık, güvenlik ve diğer alanlarda alınan önlemlerle kırsal bölgelerde yaşayan sakinlerin yaşam standartları gelişmiştir. Ayrıca son yıllarda, Çin'in "köprübaşı stratejisi” ve Çin-ASEAN Serbest Ticaret Bölgesinin kapsamlı olarak uygulanmaya konulmasıyla Çin'in Yunnan bölgesi başta olmak üzere güneybatı sınırındaki etnik bölgeler, iyi kalkınma fırsatlarına ulaşmaya başlamışlardır. ${ }^{22} \mathrm{Bu}$ bölgelerdeki sosyo-ekonomi sürekli gelişmekte olup sakinlerin yaşam standartları devamlı olarak iyileşmektedir. Bu nedenle, güneybatı sınırının sosyo-ekonomik açıdan hızlı gelişimi, toplumsal istikrarı ve sosyal yaşam koşullarının iyileşmesi, Çin-Güneybatı sınırında

Üsküdar

University

Journal of Social

Sciences, 2021; issue: 13 , 333-374 uluslararası evlilikler yapan Vietnamlı kadınlar için önemli çekici faktörler

${ }^{22}$ Yunnan ekonomisinin ve toplumunun iyi ve hızlı bir şekilde gelişimini teşvik etmek açısından büyük önem taşımaktadır, güncellme 27 Ocak 2021, erişim 21 Temmuz 2010, https://baike.baidu.com/item/\%E6\%A1\%A5\%E5\%A4\%B4\%E5\%A0\%A1\%E6\%88\%9 8\%E7\%95\%A5

“Köprübaşı Stratejisi” (“Qiaotoubao Zhanlue 桥头堡战略”), Temmuz 2009’da Çin Başkanı Hu Jintao'nun Yunnan'ı ziyaret etmesiyle birlikte, Yunnan'ı Çin'in güneybatıya açılması için önemli bir köprü olarak görmesiyle başlamıştır. "Köprübaşı stratejisi," Çin'in güneybatıya açılmasını teşvik etmek ve komşular ile dostane ilişkiler kurmak için oluşturulmuş stratejik bir ihtiyaçtır. Aynı zamanda Yunnan'ın "sınır bölgelerini iyileştirmek ve halkı zenginleştirmek" projesini teşvik etmek ve sınırdaki azınlıkları yoksulluktan kurtarmak ve iyi bir toplum kurmak için gerçekçi bir ihtiyaçlar silsilesi oluşturmaktadır. Kısacası "köprübaşı stratejisi,"

ASEAN Serbest Ticaret Bölgesi (“Zhongguo- Dongmeng Ziyou Maoyiqu中国-东盟 自由贸易区”). ASEAN: Güneydoğu Asya Ülkeleri Birliği (Association of Southeast Asian Nations)'nin kısaltmasıdır, üye ülkeler arasında Malezya, Endonezya, Tayland, Filipinler, Singapur, Brunei, Vietnam, Laos, Myanmar ve Laos bulunmaktadır. Çin ve ASEAN arasındaki diyalog ve alışverişler 1991'de başlamıştır ve 1 Ocak 2010'da Çin -ASEAN Serbest Ticaret Bölgesi resmi olarak başlamıştır, güncellme 12 Aralık 2020, erişim 8 Ocak 2010, https://zh.wikipedia.org/wiki/\%E4\%B8\%AD\%E5\%9B\%BD\%EF\% BC\%8D\%E4\%B8\%9C\%E7\%9B\%9F\%E8\%87\%AA\%E7\%94\%B1\%E8\%B4\%B8\%E6\%9 $8 \% 93 \% \mathrm{E} 5 \% 8 \mathrm{C} \% \mathrm{BA}$. 


\section{Çin’in Güneybatı Sınırında Yapılan Uluslararası Evliliklerdeki "Vietnamlı Kadın"}

haline gelmiştir. ${ }^{23}$ Yani Vietnamlı kadınların uluslararası evlilik yapmasının en temel sebebi ekonomik olarak rahat bir yaşam sürme isteğidir. Diğer yandan, Vietnam sınırındaki bölgeler nispeten fakirdir ve bu yüzden birçok kadın kendi ekonomik durumunu değiştirmek ve sosyal yaşam koşullarını iyileştirmek için Çinli erkekler ile evlenmeyi tercih ederler ${ }^{24}$ Çünkü Vietnam sınırındaki bazı köyler nispeten geride kalmıştır. Temel yaşamsal ürünlerin daha az olmasından dolayı bu köyler, günlük ihtiyaçlarını veya tarımsal üretim için gerekli olan gübrelerin ve tohumların çoğunu Çin’den satın alır hâle gelmişlerdi. ${ }^{25}$ Dolayısıyla Vietnamlı kadınların Çinli erkekler ile evlenmesinin itici gücünü yaşam koşulları oluşturmaktadır. Kısacası, göç sosyolojisindeki itme-çekme teorisinin bakış açısıyla bakıldığında, Çin-Vietnam sınırındaki iki ülke arasında sosyal ve ekonomik gelişmişliğin farklı seviyelerde olması, çok sayıda Vietnamlı kadının Çin’e göç edip Çinli erkeklerle evlenmelerinin itici ve çekici gücü olmuştur.

Üçüncü olarak, Çin-Vietnam arasında yaşayan erkek ve kadın oranlarının dağılımdaki dengesizlik, bu sınırda uluslararası evliliklerin ortaya çıkmasınıniçselsebebidir.Biryandan, Çin’ingüneybatısınırlarındaki cinsiyet dağılımına bakıldığında, uzun zamandan beri sergilenen ataerkil tutum nedeniyle erkeklerin ve kadınların oranının dengede olmadığı

Üsküdar

Üniversitesi

Sosyal Bilimler Dergisi, 2021;

sayl: 13 , $333-374$

${ }^{23} \mathrm{Gu}$, Jiarong 谷家荣, “Diyu、Shenfen Yu Rentong---Yunnan Jinshuihecun Daizu Kuaguo Hunyin Diaocha地域、身份与认同——云南金水河村傣族跨国婚姻调 查,” Qinghai Minzu Yanjiu青海民族研究, 20, say1: 4, (Ekim 2009): 5-9, https://kns. cnki.net $/ \mathrm{KCMS} /$ detail/detail.aspx ?dbcode $=\mathrm{CJFQ} \&$ dbname $=\mathrm{CJFD} 2009 \&$ filename $=$ QHMJ200904004\&v=MzI2MDdTN0RoMVQzcVRyV00xRnJDVVI3dWZZdVJ2 Rnkva1dyck5OQ1hHWkxHNEh0ak1xNDlGWUISOGVYMUx1eFk=.

${ }^{24}$ Huang, Xueyan 黄雪燕, “Zhongyue Bianmin Kuaguo Hunyin Wenti Tanxi---Dui Guangxi Napoxian Bainanxiang Bianmin Yu Yuenan Bianmin Feifa Tonghun de Diaocha 中越边民跨国婚姻问题探析---对广西那坡县百南乡边民与越南边民非法通 婚的调查," Chuangcheng传承, say1: 4, (2014): 106-107, https://doi.org/10.16743/j. cnki.cn45-1357/d.2014.04.042; Lei, Guangming雷光明, Wang, Baotong王保同, 7278; Chen, Xun, 陈讯, 5-11.

${ }^{25}$ Luo, Liuning 罗柳宁, Long, Yao龙耀, 15-21. 


\section{Liping HU}

görülmektedir. 2020 yll sonunda Çin>de yapılmış olan yedinci nüfus sayımı verilerine göre, Çin anakarasındaki toplam nüfus yaklaşık 1,411 milyar olup, toplam nüfusun \%51,24'ünü 723,34 milyon ile erkekler oluştururken, \%48,76'inı 688,44 milyon ile kadınlar oluşturmaktadır. Toplam nüfusun cinsiyet oranı (100 kadın ve erkeklerin kadınlara oranı) 105,07 ve doğumdaki cinsiyet oranı 111,3'tür. ${ }^{26}$ Günümüzde Çin'in nüfusunun cinsiyet yapısı iyileşmiş olsa da, erkek nüfusu kadın nüfusa göre 3,490 milyon daha fazladır. Bu demektir ki günümüz Çin toplumunda evlenme yaşına gelmiş erkeklerin sayısı kadınların sayısından çok daha fazladır.

Üsküdar

University

Journal

of Social

Sciences, 2021;

issue: 13 ,

333-374

Tablo 1. 2021 Yılında Yapılmış Olan Çin'in Yedinci Nüfus Sayımı Verilerinden Alınmış Cinsiyete Göre Nüfus Dağılımı

\begin{tabular}{|l|c|c|c|c|}
\hline \multirow{2}{*}{ Toplam Nüfus (milyar) } & \multicolumn{2}{|c|}{ Erkek } & \multicolumn{2}{c|}{ Kadın } \\
\cline { 2 - 5 } & $\begin{array}{c}\text { Nüfus } \\
\text { (milyon) }\end{array}$ & Oran & $\begin{array}{c}\text { Nüfus } \\
\text { (milyon) }\end{array}$ & Oran \\
\hline 1,411 & 723,34 & $\% 51,24$ & 688,44 & $\% 48,76$ \\
\hline $\begin{array}{l}\text { Toplam Nüfusun Cinsiyet } \\
\text { Oranı (Erkek/Kadın) }\end{array}$ & \multicolumn{4}{|c|}{105,07} \\
\hline $\begin{array}{l}\text { Doğumdaki Cinsiyet Oranı } \\
\text { (Erkek/Kadın) }\end{array}$ & \multicolumn{4}{|c|}{111,3} \\
\hline
\end{tabular}

Kaynak: Çin Ulusal İstatistik Bürosu (www.stats.gov.cn)

Aynı zamanda, Çin'in sınır bölgelerinde yaşayan çok sayıda Çinli kadın, iç bölgelerdeki şehirlere sosyo-ekonomik açıdan daha refahı yüksek bir hayat yaşamak için çalışmaya gitmektedir. Şehirlere gidip çalışan genç kadınların çoğu, gelirlerinin artması ve ufuklarının

${ }^{26}$ Çin Ulusal İstatistik Bürosu, erişim 11 Mayıs 2021, http://www.stats.gov.cn/tjsj/ zxfb/202105/t20210510_1817176.html. 


\section{Çin’in Güneybatı Sınırında Yapılan Uluslararası Evliliklerdeki "Vietnamlı Kadın"}

genişlemesiyle birlikte evlenmek ve yaşamak için memleketlerine dönmek yerine, çalıştıkları şehirlerde kalmayı veya başka yerlerden gelen işçilerle evlenmeyi tercih etmektedirler. Bu bağlamda Çin'in güneybatı sınırında yaşayan erkekler, erkek nüfusun fazla olmasından dolayı evlenebilecek uygun kadını bulmakta zorlanabilmektedirler. Öte yandan, Vietnam'daki cinsiyet dağılımına bakıldığında, Vietnam'ın uzun savaş döneminden dolayı Vietnamlı genç erkeklerin, kadınlara oranla daha az olduğu ortaya çıkmıştır. Yani Vietnam'ın atlattı̆g bu savaş sonucunda cinsiyet dağılımında erkeklerin aleyhinde ciddi bir dengesizlik meydana gelmiştir. Bu bağlamda Vietnam ve Çin'in güneybatı sınır bölgelerinde bu durum Vietnamlı kadınların ve Çinli erkeklerin birbiriyle evlenmelerine olanak sağlamaktadır. Bu nedenle, bu uluslararası evlilikler, Çin'in kırsal bölgelerindeki erkek nüfusun fazla olması nedeniyle bazı erkeklerin uygun bir eş bulamaması sorununu ve Vietnam'daki kadınların fazla nüfusunun neden olduğu evlilik dengesizliği sorununu çözebilmektedir. ${ }^{27}$

\section{2. Çin'in Güneybatı Sınırında Uluslararası Evlilikler Yapan Vietnamlı Kadınların Durumları}

Çin'in güneybatısındaki Çin-Vietnam arasındaki uluslararası evlilikler, bir açıdan, cinsiyet oranındaki dengesizlikten kaynaklanan Çin'in ekonomik anlamda gelişmemiş sınır bölgelerindeki evlenebilecek uygun bir kadın bulamayan erkeklerin, komşu ülkelerin sınır bölgelerindeki kadınlarla evlenme eğiliminde olmalarının yarattığı "evlilik

\footnotetext{
${ }^{27}$ Luo, Wenqing 罗文青, 52-56; Li, Bihua, 李碧华, “Youliyu Shehuizhiwai De Qunti--Guangxi Tiandengxiang Zhongyue Kuajing Feifa Hunyin Diaocha 游离于社会之外的 群体一一广西天等县中越跨境非法婚姻调查, D Dongnanya Zongheng, 东南亚纵 横, say1: 9, (2008): 60-66; https://kns.cnki.net/KCMS/detail/detail.aspx?dbcode $=\mathrm{CJFQ} \& \mathrm{dbname}=\mathrm{CJFD} 2008 \&$ filename $=\mathrm{DLYZ2} 00809014 \& \mathrm{v}=\mathrm{MTM} 2 \mathrm{O}$ TVFWUISOGVYMUx1eFlTNORoMVQzcVRyV00xRnJDVVI3dWZZdVJ2RnkvZ1c3 N05JU0hTZExHNEh0bk1wbzk=; Lei, Guangming 雷光明, Wang, Baotong王保同, 72-78; Chen, Xun, 陈讯, 5-11.
}

Üsküdar

Üniversitesi

Sosyal Bilimler Dergisi, 2021;

sayı: 13 , $333-374$ 


\section{Liping HU}

krizi” fenomeninin bir sonucudur. Diğer açıdan, bu uluslararası evlilikler, Vietnamlı kadınların ekonomik ve sosyal gerçeklikler ve ekonomik çıkarlar tarafından yönlendirilen rasyonel seçimleridir. Bu durum, Çin'in güneybatısındaki uluslararası evliliklerde evlenen iki tarafın da aslında zayıf bir durum içerisinde olduğunu göstermektedir. ${ }^{28}$

Çin tarafından bakıldığında, son yıllarda, Çin’in evlilik piyasasında kız için ödenen başlık parasının çok yüksek olmasından dolayı ekonomik durumu iyi olmayanlar, özellikle de Çin'in güneybatı sınırındaki kırsal bölgelerde yaşayan Çinli erkekler, yüksek olan başlık paralarını ödeyememektedir. Ayrıca Çin'in güneybatı sınırındaki bölgelerde ekonomik ve sosyal kalkınmanın görece gecikmesi nedeniyle, buradaki

Üsküdar

University

Journal

of Social

Sciences, 2021;

issue: 13 ,

333-374 erkekler, evlilik piyasasından dışlanmış durumdadırlar ve bundan dolayı giderek daha büyük bir bekâr erkek kitlesi ortaya çıkmaktadır. ${ }^{29}$ Bu yüzden Çin'in güneybatı sınırındaki kırsal bölgelerde çoğu erkek yoksul olduğu için evlenme şansı bulamamaktadır. Vietnam tarafından bakıldığında ise, Vietnam sınırında yaşayan sıradan köylü bir kız yoksulluk nedeniyle ebeveynleri tarafından iyi bir çeyiz sağlanamadığı için Vietnam evlilik piyasasında dezavantajlı konuma düşmektedir. Özellikle, boşanmış, dul ve fiziksel engelli bir kadın Vietnam'ın evlilik piyasasında güçlü bir sosyal dışlanma yaşadığı için Vietnam'daki iyi ve avantajlı durumda olan erkekler ile evlenememektedir. ${ }^{30} \mathrm{Bu}$ nedenle, evlenme yoluyla Çin'e girip Çin’e yerleşen Vietnamlı eşlerin çoğu sadece yasadışı evlilik durumuyla değil, aynı zamanda yoksullukla da karşı karşıya kalmaktalardır.

\footnotetext{
${ }^{28}$ Tao, Zixiang, 陶自祥, 90-103.

${ }^{29}$ Wang, Xiaodan王晓丹, “Zhongyue Bianjing Kuaguo Hunyinzhong Nüxing Hunyin Qianyi de Yunayin He Yingxiang中越边境跨国婚姻中女性婚姻迁移的原因和影 响——以云南省文山州为例, ” Chuxiong Shifan Xueyuan Xuebao楚雄师范学院 学报, 26, say1: 8, (2011): 91-95, http://220.191.224.148:9001/KCMS/detail/detail. aspx? filename $=$ CXSZ201108018 \&dbcode $=$ CJFQ \&dbname $=$ CJFD2011.

${ }^{30}$ Tao, Zixiang, 陶自祥, 90-103.
} 


\section{Çin’in Güneybatı Sınırında Yapılan Uluslararası Evliliklerdeki "Vietnamlı Kadın"}

\section{1. Çin-Vietnam Uluslararası Evlilikleri Çoğunlukla Kayıtdışı Olması}

Çin ve Vietnam arasındaki sınır bölgesinde yapılan evliliklerin resmi bir kaydını yaptırmak zordur. Çin’in yasalarına göre, Çin’in güneybatı sınırındaki uluslararası evliliklerin şartları ve prosedürleri Çin yasalarına tabi olmalıdır. Özellikle 17 Şubat 1995 tarihinde çıkarılan "Çin ve Komşu Ülkelerin Halkları Arasında Evlilik Kayıtlarının Yönetimine Yönelik Deneme Yöntemleri” ve "Çin Halk Cumhuriyeti’nin Yabancı Evlilik Yönetimi”ne göre, Çin ve komşu ülkelerin sınırlarında evlenecek erkek ve kadınların, ayrı ayrı bizzat resmi evlilik kaydı yaptırmak için gerekli makamlara başvurup kayıt yaptırma zorunluluğu bulunmaktadır. Ancak, "Çin ve Komşu Ülkelerin Halkları Arasında Evlilik Kayıtlarının Yönetimine Yönelik Deneme Yönetimi”ne göre, bu uluslararası evlilik yapacaklar, evlilik kayıtlarını tamamlamak için şu belgeleri hazırlamak zorundadırlar: (1) yabancı kadınlar için, onların kimliğini kanıtlayabilen geçerli bir pasaport, (2) uluslararası seyahat belgesi veya sınır bölgelerine giriş ve çıkış izinleri gibi kimlik belgeleri, (3) Vietnam tarafından verilen ve Vietnam'daki Çin Halk Cumhuriyeti’nin elçiliği (konsolosluğu) tarafından onaylanan evlenecek kişilerin bekâr olduklarına dair belge veya komşu Vietnam'ın sınır bölgesindeki ilçesinin (kasaba) halk hükümeti ve Çin sınır bölgesindeki ilçesinin (kasabanın) aynı düzeyinde hükümet tarafindan verilen kişilerin eşsiz belgeleri (veya bekâr belgeleri). Ancak, Vietnamlı kadınlar için Vietnam'da kimlik belgelerini almak pek kolay değildir. Genelde, Vietnamlı kadınlar kimlik belgelerini almak için birden fazla devlet dairesine gidip işlem yaptırmak zorunda kalmaktadırlar. Aynı zamanda uygulanan prosedürler de çok karmaşık olmakta ve kadınlar çok zaman ve paraya ihtiyaç duymaktadır. Bu sebeplerden dolayı uluslararası evlilik yapan Vietnamlı kadınlar Çin yasalarının ve yönetmeliklerinin gerektirdiği belgeleri sağlamakta zorlanmakta yada sağlayamamaktadır. $\mathrm{Bu}$, Çin'in güneybatı sınırında uluslararası evlilik yapanların düzgün ve 


\section{Liping HU}

normal bir şekilde evlilik kaydı yapamadıkları anlamına gelmektedir. $\mathrm{Bu}$ yüzden, Çin'in güneybatı sınırında uluslararası evlilik yapanların çok azı evlilik kaydı yapmaktadır ve kalanların çoğu yasadışı evlilikle yaşamaktadırlar. Dolayısıyla onlar ve Çinli eşleri çevrelerine, akrabalarına veya arkadaşlarına ancak bir yerel düğün töreni ile evlendiklerini kanıtlamaktadırlar. ${ }^{31}$ Bir araştırmaya göre, Çin’in güneybatı sınırındaki bölgelerde yaşayan erkeklerle evlenen Vietnamlı kadınların \%85'inin uluslararası evlilik için uygulanan resmi kayıt prosedürlerinin karmaşıklığı, ekonomik durumlarının zayıflığı ve yasal bilgilerinin eksikliği gibi sebeplerden dolayı resmi evlilik kaydı bulunmamaktadır. ${ }^{32}$

Üsküdar

University

Journal of Social

Sciences, 2021; issue: 13 , 333-374

\section{2. Çin'in Güneybatı Sınııında Yaşayan Vietnamlı Eşlerin Yoksulluğu}

"Batı Kalkınma Stratejisi” ve "Sınırlardaki sosyo-ekonomiyi İyileştirme ve İnsanları Zenginleştirme” projeleri gibi politikaları uygulamasıyla, Çin'in güneybatı sınırında sosyo-ekonomik durumu geliştirmesine ve halkların refah seviyesini iyileştirmesine rağmen bu bölgelerde bazı sınırlar günümüzde hala yoksul durumdadır ve çoğu sınır, ekonomik açıdan geri kalmış bölgelerden oluşmaktadır. ${ }^{33} \mathrm{Bu}$ bölgelerde Vietnamlı kadınlarla evlenen Çinli erkekler de çoğunlukla bu bölgelerdeki yoksul hanelerdendir.

${ }^{31}$ Luo, Liuning 罗柳宁, Long, Yao 龙耀, 15-21; Wang, Binbin 王涁涁, Li, Kaidong李 凯冬, “Zhongyue Bianjing Kuaguo Hunyindui Bianjing Cunluo Zhili de Yingxiang---Yi Gejiecun Hanizu Weili 中越边境跨国婚姻对边境村落治理的影响---以隔界村哈尼 族为例," Honghe Xueyuan Xuebao红河学院学报, 15, sayı: 4, (2017): 16-18, https:// doi.org/10.13963/j.cnki.hhuxb.2017.04.004.

32 Tao, Zixiang 陶自祥, 90-103.

33 “Batı Kalkınma Stratejisi” (“Xibu Dakaifa Zhanlüe西部大开发战略”), Çin’in doğu ve batı bölgeleri arasındaki sosyo-ekonomik kalkınma dengesizliğinden dolayı Çin'in batı bölgeleri çok ekonomik olarak geri kalmış durumdadır. Çin’in batı bölgelerinin geliştirilmesi için bu Batı Kalkınma Stratejisi bu yüzyılın başında önerilmiş bir stratejidir. Bu kalkındırılması amaçlanan bölgelere Chongqing, Sichuan, Guizhou, Yunnan, Tibet Özerk Bölgesi, Shaanxi, Gansu, Çinghay, Ningxia Hui Özerk Bölgesi, Sincan Uygur 


\section{Çin’in Güneybatı Sınırında Yapılan Uluslararası Evliliklerdeki "Vietnamlı Kadın"}

Bu yüzden, Çinli erkeklerle evlenmiş olan ve Çin'in güneybatı sınırında yaşamakta olan Vietnamlı kadınların ekonomik durumları nispeten daha kötüdür. ${ }^{34}$

Ayrıca, Vietnamlı kadınlar Çin'de bir ikametgâh kaydı ve vatandaşlık elde etmekte zorlandıkları için Çin'de yoksulluk ve zor yaşam koşulları ile karşı karşıya kalmaktadırlar. Zira bir toplum üyesinin sosyal kimliği sadece toplumsal tanınılık anlamina gelmemekte, aynı zamanda toplumun maddi yaşamının temelini de oluşturmaktadır. Çin'de yaşayan Vietnamlı kadınların çoğunluğu bir yandan Çin'de uzun süre yaşadıkları için Vietnam vatandaşlıklarını kaybederken, diğer yandan da Çin vatandaşlığı alamadıkları için "vatandaş olmayan kadın" haline gelmiştir. ${ }^{35} \mathrm{Bu}$ durumda yaşayan Vietnamlı eşler Çinli vatandaşların temel haklarından yararlanamamaktadırlar. Örneğin, onların Çin'de oturma izni olmaksızın

Özerk Bölgesi, İç Moğolistan Özerk Bölgesi, Guangxi Zhuang Özerk Bölgesi gibi 12 il veya özerk bölge veya şehir dahildir. Güncelleme 9 Nisan 2021, erişim, 3 Ağustos 2017, https://baike.baidu.com/item/\%E8\%A5\%BF\%E9\%83\%A8\%E5 \%A4\%A7\%E5\%BC\%80\% E5\%8F\%91\%E6\%88\%98\%E7\%95\%A5.

${ }^{34}$ Luo, Liuning 罗柳宁, Long, Yao 龙耀, 15-21; Wang, Binbin 王涁涁, Li Kaidong 李 凯冬, 16-18.

${ }^{35} \mathrm{Lu}$, Haifa 陆海发, “Bianjing Kuaguo Hunyin Yimin Zhili: Tiaozhanyu Pojie Zhidao 边境跨国婚姻移民治理: 挑战与破解之道, ” Xinan Minzu Daxue Xuebao (Renwen Shehui Kexueban) 西南民族大学学报(人文社会科学版), 37, say1: 3, (2016): 48-53, https://kns.cnki.net/KCMS/detail/detail.aspx?dbcode=CJFQ\&dbname =CJFDLAST 2016\&filename $=$ XNZS201603009\&v=MDQ2OTBmTXJJOUZiWVI4ZVgxTHV4WV M3RGgxVDNxVHJXTTFGckNVUjd1Zll1UnZGeTdtVUwvTVBTUFJmYkc0SDk=.

Çin yasasına göre, Çinli erkekler ile evlenip Çin'de yaşayan bu Vietnamlı kadınlar Çin'de beş sene oturmaları halinde (bu beş sene içinde her sene en an az 9 ay Çin'de bulunması gerekir) kalıcı oturma izni alabilirler ve bu kalıcı oturma izinleri ile Çin vatandaşlığını başvuruda bulunabilirler. Ancak, bazı sebeplerden dolayı Vietnam'dan ilgili yasal kimlik belgelerini alamadıkları için Çin vatandaşlığı için başvuruda bulunamazlar ve Çin vatandaşlığı alamazlar. Dahası, Çin'de yaşadıkları için Vietnam vatandaşlıklarını da kaybederler. Bu nedenle, "vatandaş olmayan kadın” statüsünde yaşamaktalardır ( $\mathrm{Li}$, Juan 李娟, Luo, Liuning, 7-14). 


\section{Liping HU}

yaşamasından dolayı, Çin’e serbestçe girip çıkmaları mümkün değildir ve onlar için şehirlere gidip çalışmak da oldukça zordur. ${ }^{36}$ Çin vatandaşlı̆̆ına ve aile kaydına sahip olmadıkları için, bu Vietnamlı kadınların Çin'de kendi arazileri olması olanaksızdır. Dahası bu kadınlar, kırsal ekonomik temettüler, bağış sigortası ve sağlık sigortası vb. herhangi bir sosyal güvenceye başvuramaz, sosyal güvenlik avantajından yararlanamazlar, şehirlerde serbestçe bir iş bulamazlar. ${ }^{37}$ Şehirlerde çalışabilseler bile, kimlik kartları ve aile hane halkı kaydı gerektirmeyen işlerde çalışabilmekte, genellikle bu kadınların maaşları da oldukça düşüktür. ${ }^{38} \mathrm{Bu}$ durum, Vietnamlı kadınları daha zor bir duruma düşürmekte ve Vietnamlı eşlerle

Üsküdar

University

Journal

of Social

Sciences, 2021;

issue: 13 ,

333-374

evlenen erkeklerin ekonomik koşulları da iyi olmadığı için aile içindeki yoksulluk düzeyini artırmaktadır.

${ }^{36} \mathrm{Gu}$, Jiarong, 5-9.

${ }^{37}$ Luo, Liuning, 罗柳宁, Long, Yao 龙耀, 15-21; Bao, Yueping 保跃平, “Xuanzeyu Kunjing: Yunnan Bianjing Kuaguo Hunyin de Shehuixue Fenxi, 选择与困境: 云南边境跨国婚 姻的社会学分析, Beifang Minzu Daxue Xuebao (Zhexue Shehui Kexueban)北方民 族大学学报(哲学社会科学版), say1: 4, (2013): 5-12, https://kns.cnki.net/KCMS/ detail/detail.aspx ?dbcode $=$ CJFQ $\&$ dbname $=$ CJFD2013\&filename $=$ XBDR201304002 \&v=MDE1Njk5TE1xNDlGWm9SOGVYMUx1eFITN0RoMVQzcVRyV00xRnJDVV I3dWZZdVJ2Rnk3blZyM09QUy9QZkxHNEg=; Lu, Haifa, 陆海发, "Bianjing Zhilizhong de Kuaguo Hunyin Yimin: Tezheng, Dongli Jiqi Yingxiang --- Jiyudui Yunnan Liangge Biangjingxian e Diaochayu Sikao边境治理中的跨国婚姻移民: 特征、动力 及其影响---基于对云南两个边境县的调查与思考, Yunnan Minzu Daxue Xuebao (Zhexue Shehui Kexueban)云南民族大学学报（哲学社会科学版) 34, say1: 5, (2017) : 62-70, https://doi.org/10.13727/j.cnki.53-1191/c.2017.05.011.

${ }^{38}$ Fang, Tianjian 方天建, “Zhongyue Bianjing Kuajing Minzu Hunyin Diaochayu Fenxi--Yi Yunnansheng Funingxian Tianpengzhen, Muyangzhen Weili 中越边境跨境民族婚 姻调查与分析——以云南省富宁县田蓬镇、木央镇为例, Minzu Xuekan民族学 刊, 6, say1: 6 (2015): 55-67, https://kns.cnki.net/KCMS/detail/detail .aspx?dbcode= CJFQ\&dbname $=$ CJFDLAST2016\&filename $=$ MZXK201506010\&v=MDc1NTg3TUt EZlRaYkc0SDIUTXFZOUVaSVI4ZVgxTHV4WVM3RGgxVDNxVHJXTTFGckNVUj d1Zll1UnZGeTdnVkw=. 


\section{Çin’in Güneybatı Sınırında Yapılan Uluslararası Evliliklerdeki "Vietnamlı Kadın"}

\section{Bu Tip Evliliklerin Çin'in Güneybatısında Neden Olduğu Sosyal Sorunlar}

Son yıllarda, Çin-Vietnam arasındaki uluslararası evliliklerin Çin'in güneybatı sınırındaki bölgelerde daha yaygınlaşmasıyla, Çin'in bazı kırsal bölgelerinde başlık paralarının yüksek olmasından dolayı, Çin'in güneybatısındaki köylerde yaşayan ileri yaştaki bekâr erkeklerin evlilik sorunlarını çözmeyi kolaylaştırabilmekte ve bir dereceye kadar da Çin'in sınır toplumunun istikrarını ve uyumunu destekleyebilmektedir. Ayrıca, bu tür uluslararası evlilikler Çin-Vietnam arasındaki ekonomik iş birliğini ve kültürel etkileşimi teşvik etmeye yardım etmektedir. Fakat bu Vietnamlı eşlerin çoğu yasadışı olarak evlenip Çin’de yasadışı olarak yaşadıkları için Çin'in güneybatı bölgelerinde bir dizi sosyal sorunlar ortaya çıkmakta ve bu haliyle sınır bölgesinin sosyal istikrarına ve sınır toplumunun uyumlu bir sosyal düzeninin inşasına elverişli değildir.

İlk olarak, evlilik ilişkisi perspektifinden bakıldığında, bir yandan, Çin'in güneybatı sınırında yaşayan Vietnamlı kadınlar ve Çinli erkekler arasındaki evlilik ilişkisinin yasadışı olması bu kadınların evlilikte eşitlikten yoksun bir konumda yaşamalarına neden olmaktadır. Çinlilerle evlenmiş Vietnamlı kadınlar "vatandaş olmayan kadın” durumuna düştükleri için Çin'de sosyal statüleri nispeten düşüktür ve toplumda politik ve sosyal katılım açısından bu kadınların temel haklardan yoksun olması dolayısıyla, genelde sosyal ve kamusal aktivitelere çok katılamazlar ve toplumdaki bazı üretim faaliyetlerinde yine sadece kocalarına bağlı olup, bağımsız olarak bu tür faaliyetlerle ilgilenemezler. ${ }^{39} \mathrm{Bu}$ nedenle, bu Vietnamlı kadınlar aile statüsünde aşağı konumda bulunmakta ve onların düşük aile statüleri Çinli eşleriyle olan evliliklerindeki eşitsizliğin nedenlerinden biridir. Öte yandan, daha önce belirtildiği gibi, bu uluslararası evliliklere genellikle yasadışı evlilikler hâkim olmasından dolayı evlilik ilişkileri istikrarlı

${ }^{39}$ Luo, Liuning罗柳宁, Long, Yao 龙耀, 15-21; Bao, Yueping 保跃平, 5-12.

Üsküdar

Üniversitesi

Sosyal Bilimler

Dergisi, 2021;

sayl: 13 ,

$333-374$ 


\section{Liping HU}

değildir. Çin'in güneybatı sınırında yaşayan Çinli erkekler sınırlara girme çıkma kolaylığını ve herhangi bir yasal prosedürün yokluğunu firsat bilerek Vietnamlı kadınlarla fiili evlilik ilişkileri kurmaktadırlar. Fakat bu tür evlilik ilişkileri yasal kısıtlamalardan ve korumalardan yoksundur. $\mathrm{Bu}$ nedenle, Çinlilerle evlenip Çin'de çocuk doğuran bazı Vietnamlı kadınlar aile çatışmaları veya başka sebeplerden dolayı evden kaçıp Vietnam’a dönmeyi ya da Çin'in diğer bölgelerinde yeniden evlenmeyi seçebilirler. ${ }^{40}$

İkinci olarak, aile fonksiyonu açısından bakıldığında, bu tür uluslararası evlilikler, aile işlevlerinin tam olarak yerine getirilmesine yardımcı olmaz. Genel olarak, aile fonksiyonu, aile varlığının sosyal temelidir ve bir aile ekonomik üretim, doğurganlık, eğitim, yetiştirme ve destekleme, güvenlik

Üsküdar University Journal of Social

Sciences, 2021; issue: 13 , 333-374 gibi farklı fonksiyonlara sahiptir. Ancak, Çin'in güneybatı sınırındaki Çin-Vietnam uluslararası evlilikleri hem yasadışı oldukları için bu karma ailelerin ekonomik fonksiyonu, eğitim fonksiyonu, psikolojik güvenlik fonksiyonu dahil olmak üzere birkaç aile fonksiyonunu iyi bir şekilde sağlayamazlar. Ailenin ekonomik fonksiyonu açısından, Çin'in güneybatı sınırındaki Vietnamlı kadınlarla evlenmiş Çinlilerin çoğunun, ekonomik temelleri zayıf ve sosyal kaynaklara erişiminin nispeten kısıtlı olmasından dolayı evlendikten sonra ailenin yoksulluğu gibi ekonomik sorunlar çözülememektedir ve bu ailelerinin çoğu hala yoksuldur. Özellikle Çin sınırındaki dağlık ve ekonomileri gelişmemiş bölgelerde yaşayan halkların çoğu başka ekonomik gelirleri olmadığı için sadece sınırlı araziye bağlı olarak hayatta kalmaktadır. Yukarda bahsedildiği gibi, bu tür uluslararası evlilikte Vietnamlı kadınlar Çin vatandaşlığına ve Çin'deki hane halkı

\footnotetext{
${ }^{40} \mathrm{Li}$, Xueyan 李雪岩, Long, Yao 龙耀, “Zhongyue Bianjing Kuaguo Hunyin Wenti Yanjiu (Funüpian) 中越边境跨国婚姻问题研究 (妇女篇) ----以广西大新县德天 村为例," Shijie Minzu世界民族, say1: 4, (2008): 75-80, https://kns.cnki.net/KCMS/ detail $/$ detail.aspx ?dbcode $=$ CJFQ $\&$ dbname $=$ CJFD2008 \&filename $=$ TRIB200804011 \&v=MDAwNDFyQ1VSN3VmWXVSdkZ5N2hXcnpQTVQvQ2JMRzRIdG5NcTQ5 RVpZUjhlWDFMdXhZUzdEaDFUM3FUcldNMUY=.
} 


\section{Çin’in Güneybatı Sınırında Yapılan Uluslararası Evliliklerdeki "Vietnamlı Kadın"}

kaydına sahip olmadıklarından dolayı arazi edinemezler ve Çin'in ulusal yasa ve politikalarının yardımlarından yararlanamazlar. ${ }^{41} \mathrm{Bu}$ nedenle, zaten fakir olan aileler daha da yoksul olarak yaşamaya devam etmektedir.

Ailenin eğitim fonksiyonu bakımından, Çin'in güneybatı sınırında Çin-Vietnam uluslararası evlilik yoluyla oluşan ailelerde yaşayan çocuklar, ailelerindeki ikili kültürel kökenler nedeniyle genellikle annelerinden Çin kültürü dışında farklı bir kültür öğrenmelerine rağmen, ebeveynlerinin evliliğinin yasallı̆̆ problemi sosyalleşme sürecinde ikilemlere yol açmıştır. $^{42} \mathrm{Bu}$ uluslararası evlilikteki çocuklar annelerinin sosyal kimliğinin net olmamasından dolayı ailelerinin düşük sosyal statüsünde yaşamaktadırlar ve annelerinin durumlarından dolayı bu çocuklarda aşağılık kompleksi oluşabilmektedir. ${ }^{43}$ Ayrıca, ebeveynlerin yasallık sorunu, onların çocuklarının eğitimi konusundaki yasallık ve yasadışılık kavramlarını da anlama sorununa neden olmaktadır. Bu çocuklar yasadışı göç, gayrimeşru çocuk, kaçakçılık ve benzeri eylemlerle karşı karşıya kaldıklarında bir karmaşa ve sorun yaşamaktadırlar."4 Bunun dışında bazı

Üsküdar

Üniversitesi

Sosyal Bilimler Dergisi, 2021;

sayl: 13 , $333-374$

${ }^{41}$ Huang, Liuran黄流然、Li, Juan 李娟、Long, Yao龙耀, “Zhongyue Bianjing Kuaguo Hunyin Wenti de Shehuixue Sikao 中越边境跨国婚姻问题的社会学 思考, " Liaoning Xingzheng Xueyuan Xuebao(Shehui Renwen) 辽宁行政学院学 报(社会人文), say1: 1 (2008): 201-202, https://kns.cnki.net/KCMS/detail/detail. aspx dbcode $=$ CJFQ \&dbname $=$ CJFD2008\&filename $=$ LLXY200801112\&v $=$ MTAxMDg3 RGgxVDNxVHJXTTFGckNVUjd1Zll1UnZGeUhrVTd2SOtTSFRkN0c0SHRuTXJvNU Vab1I4ZVgxTHV4WVM=.; Wang, Binbin 王彬涁, Li, Kaidong 李凯冬, 16-18.

${ }^{42}$ Huang, Xueyan 黄雪燕, 106-107.

${ }^{43}$ Li, Xueyan 李雪岩, Long, Yao 龙耀, 75-80; Huang, Liuran 黄流然、Li, Juan 李 娟、Long, Yao 龙耀, 201-202.

${ }^{44}$ Zhou, Jianxin 周建新, “Zhongyue Bianjing Kuaguo Hunyinzhong Nüxing Jiqi Zinü de Shenfen Kunjing---YiGuangxi Daxinxian Zhuangcun Gean Weili 中越边境跨国婚姻中女性及其子女的身份困境——以广西大新县壮村 个案为例,” Sixiang Zhanxian思想战线, say1: 4, (2008): 1-8, https://kns.cnki.net/ KCMS $/$ detail/detail.aspx ?dbcode $=$ CJFQ \&dbname $=$ CJFD2008\&filename $=$ SXZX2008 04003\&v=MzI0NDdmWXVSdkZ5SGxWN3JJTmpYUmRyRzRIdG5NcTQ5Rlo0Ujhl 


\section{Liping HU}

Vietnamlı kadınlar çocuk sahibi olduktan sonra, aile çatışması veya aile yoksunluğu gibi sebeplerden dolayı çocuklarını evde bırakıp Vietnam’a geri dönebilmekte veya başka yerlerde yaşayan başka Çinli erkeklere kaçabilmektedirler. Bu çocukların büyüme süreçlerinde anne bakımından yoksunluğu psikolojik sorunlar yaratabilmekte, dolayısıyla bu çocukların kaçakçılık veya suça yönelimi artış göstermektedir. ${ }^{45}$ Aynı zamanda, bazı Vietnamlı kadınlar Çinlilerle evlendiklerinde Vietnam'da doğurdukları çocukları da Çin’e getirmişlerdir. Vietnamlı anneleriyle Çin’e gelmiş bu çocuklar, Çin'de sürekli yaşamasına rağmen Çin vatandaşlığı veya hane halkı kayıtları bulunmadığı için temel eğitim haklarından yararlanamamakta ve çevrelerinde aynı yaştaki diğer çocuklar gibi dokuz yıllık zorunlu eğitime de katılamamaktadırlar. ${ }^{46}$ Ayrıca, bu tür Çin-Vietnam sınırındaki

Üsküdar

University

Journal of Social

Sciences, 2021; issue: 13 , 333-374 uluslararası evliliklerle yaşayan birçok Vietnamlı kadın, Çin toplumuna iyice entegre olamamasından dolayı çocuklarına Çin'in ulusal koşullarına uygun bir aile eğitimi verememektedir. ${ }^{47}$

Ailenin psikolojik güvenlik işlevine bakıldığında, bu uluslararası evlilikler, yasal evlilik prosedürleriyle işlenmemesinden dolayı bu uluslararası aileler aile üyeleri için gereken temel sosyal güvenlik garantilerinden yasal olarak yoksundur. Ailenin üyeleri olarak, Çinli

WDFMdXhZUzdEaDFUM3FUcldNMUZyQ1VSN3U=.

${ }^{45}$ Wang, Binbin 王涁涁, Li, Kaidong李凯冬, 16-18.

${ }^{46}$ Wang, Xiaodan 王晓丹, 91-95; Wu, Xingzhi 吴兴帜, “Zhongyue Kuajing Minzu Jiaowang yu Bianmin Shehui Zhili Yanjiu --- Yi Yunnansheng Hekou, Jinpingxian Weili 中 越跨境民族交往与边民社会治理研究——以云南省河口、金平县为例," Qinghai Shifan Daxue Xuebao (Zhexue Shhui Kexueban)青海师范大学学报(哲学社会科学版) 37, say1: 2, (2015):50-55, https://doi.org/10.16229/j.cnki.issn1000-5102.2015.02.011. ${ }^{47}$ Xie, Shangguo 谢尚果, Luo, jiayan罗家珩, “Zhongyue Bianjing Diqu Kuaguo Hunyin Zhili Mushi Fenxi 中越边境地区跨国婚姻治理模式分析,”Guangxi Minzu Yanjiu 广 西民族研究, say1: 2 (2016): 57-64, https://kns.cnki.net/KCMS/detail/detail.aspx? $\mathrm{dbcode}=\mathrm{CJFQ} \& \mathrm{dbname}=\mathrm{CJFDLAST} 2016 \&$ filename $=\mathrm{MZYA201602010} \& \mathrm{v}=\mathrm{MTQw}$ NDRiN0c0SDlmTXJZOUVaSVI4ZVgxTHV4WVM3RGgxVDNxVHJXTTFGckNVU jd1Zll1UnZGeUhtVXIvTktEZlM=; Wang, Binbin 王彬涁, Li, Kaidong李凯冬, 16-18. 


\section{Çin’in Güneybatı Sınırında Yapılan Uluslararası Evliliklerdeki "Vietnamlı Kadın"}

erkeklerin eşleri ve Çinli çocukların anneleri olan Vietnamlı kadınlar, yasadışı olarak Çin'de yaşadıkları için sıklıkla Çin'den Vietnam'a geri gönderilme riskiyle karşı karşıya kalırlar. Bu bağlamda bu kadınlar, ailede psikolojik düzenleme rolü oynamazlar. Aynı zamanda, Vietnamlı kadınların Çin'den sürgün edilmeleri, aslında bir ailede erkeğin eşini ve çocuklarının da annelerini kaybedeceği anlamına gelir, bu, tüm aile de kaçınılmaz endişeye yol açacak bir durumdadır. ${ }^{48}$

Üçüncü olarak, Çin’in güneybatı sınırındaki uluslararası evlilikler yapan Vietnamlı kadınların evlilik yaparken yasal bir kaydı yapılmadığı için bu tür evlilikler yasal korumaya sahip değildir. Bu durum erken evlilik, çocuk doğurma, tekrar evlenme ve aldatma gibi sorunlara yol açabilmekte ve Çin'in sınır bölgelerindeki sosyal düzen ve yerel yönetim üzerinde olumsuz etki yaratmaktadır. ${ }^{49}$ Aynı zamanda bu uluslararası evliliklerde Vietnamlı kadınların genel olarak yasadışı yollarla Çin’e gelmelerinden dolayı evlilik yaparken evlilik kaydı yaptırmakta, vatandaşlık başvurusunda ve aile kütügüne katılmakta zorluk yaşamaları gibi toplum yönetiminde birçok zorluk ve sorun hâlâ yaşanmaktadır. ${ }^{50} \mathrm{Bu}$ sorunlar, ülkenin giriş ve çıkış yönetiminde ve uluslararası suçların denetiminde, Çin'in güneybatı sınırındaki evlilik yönetimi ve aile planlama politikasının uygulanmasında, köyün yönetimi ve toplum düzeninin sağlanmasında ve diğer birçok işin uygulanmasında birtakım zorlukları beraberinde getirmektedir. ${ }^{51}$ Aynı zamanda Vietnamlı kadınların birçok akrabası, akraba ziyareti adı altında yasadışı olarak Çin’e girmekte olup, yasadışı olarak Çin’de kalmakta ve çalışmaktadırlar. Onlar yalnızca ülke sınırlarının güvenlik yönetimini bozup, potansiyel güvenlik tehlikeleri yaratmakla kalmamakta

\footnotetext{
${ }^{48} \mathrm{Li}$, Xueyan 李雪岩, Long, Yao 龙耀, 75-80.

${ }^{49} \mathrm{Lu}$, Haifa 陆海发, 62-70.

${ }^{50}$ Lei, Guangming 雷光明, Wang, Baotong 王保同, 72-78; Wang, Xiaodan王晓丹, 9195; Wu, Xingzhi 吴兴帜, 50-55.

${ }^{51}$ Wang, Binbin 王涁彬, Li, Kaidong 李凯冬, 16-18.
}

Üsküdar

Üniversitesi

Sosyal Bilimler

Dergisi, 2021;

sayl: 13 ,

$333-374$ 


\section{Liping HU}

aynı zamanda da Çin sınırında bulunan köylerde de yasadışı suçların artmasına sebep olmaktadırlar. Bazıları da yerel suçlular ile uluslararası kaçakçılık, uyuşturucu kaçakçılığı, kadın ve çocuk ticareti yapmakta ve bazı Vietnamlı kadınlar bile bu gibi suçlara katılmaktadırlar. ${ }^{52}$ Dolayısıyla, yasadışı göçmenler, yasadışı sakinler ve yasadışı çalışanlar arttıkça, Çin’in sınır bölgelerindeki sosyal güvenlik, kamu düzeni ve istikrarı gibi sosyal yönetim ile ilgili konuları ciddi biçimde etkilemekle kalmamakta Çin'in sınır bölgelerindeki sosyal güvenliğe ve istikrarına, kamu düzenine belli veya gizli tehlikeler getirebilmektedir.

\section{Uluslararası Evliliklerle İlgili Bazı Sosyal Düzenleme Önerileri}

Üsküdar

University

Journal

of Social

Sciences, 2021;

issue: 13 ,

333-374

Küreselleşmenin hızlanması ve ülkeler arasındaki iletişimlerin genişlemesi farklı ülkelere mensup insanların birbiriyle evlenme olasılığını artırmaktadır. Çin'in reformlarıyla birlikte ekonomisinin kalkınması, sosyal istikrarın artması ve halkın yaşam standartlarının gelişmesi, Çin’i evlilik göçmenlerinin tercih ettiği önemli ülkelerden biri hâline getirmiştir. Bu bağlamda birçok Vietnamlı kadın benzer kültür ve yaşam alışkanları, yaşam koşullarını iyileştirilmesi, ekonomik çıkar gibi sebeplerden dolayı Çin'in güneybatı sınırına gidip burada yaşayan Çinli erkeklerle yasadışı evlilik yapmışlardır. Bu tür evlilik yapan Vietnamlı kadınlar genellikle yasadışı yollarla Çin'e geldiklerinden dolayı Çin’e yerleştikten sonra Çin vatandaşlığına ve hane kaydına sahip olamadıkları için Çin'de siyasi kimlikleri olmayan marjinal insanlar olarak yaşamaktadırlar. Böylece, Çin'in güneybatı sınırında bulunan Çin-Vietnam uluslararası evlilikleri, bu tür uluslararası evlilik yapanların aile yaşamı, çocuk eğitimi ve sınırındaki sosyal yönetim gibi konularda çeşitli zorluklar ve problemleri getirmekle kalmamakta, aynı zamanda Çin'in sınır bölgelerinde toplumsal yönetim açısından zorluklar yaşanmasına sebep olmaktadır.

${ }^{52}$ Fang, Tianjian 方天建, 55-67. 


\section{Çin’in Güneybatı Sınırında Yapılan Uluslararası Evliliklerdeki "Vietnamlı Kadın"}

Çin-Vietnam sınırında bu tür evliliklerde yaşanan sorunları doğru bir şekilde çözmek ve burada yaşayan halkların refah ve istikrarı ile uyumlu bir toplumun inşasını desteklemek için bazı çözümler ve öneriler düşünülmelidir. Bazı araştırmacılar bu uluslararası evlilik olgusunun neden olduğu toplumsal sorunlar ve evliliğin getirdiği olumsuz etkiler hakkında bazı görüş ve öneriler öne sürmüşlerdir. Mesela, bazı akademisyenler, Yunnan bölgesi sınırında yaşanan yasadışı olarak uluslararası evlilikler için şu şekilde bir analizde bulunmaktadır: Yunnan sınırındaki bölgelerde yasadışı evlilikle gelen göçmen sorununu çözmek için, "tahliye etme ve engellenme," "sertlik ve yumuşaklık" yöntemini birleştirmek gerekir, aynı zamanda dış yönetim ve iç yönetimi birleştirmek de bu problemleri etkili bir şekilde çözebilir. ${ }^{53}$ Bunun dışında, bazı araştırmacılara göre ise bu yolla yapılan evlilik sorununun çözümü, sınırdaki ülkeler arasında iletişim ve işbirliğinin güçlendirilmesi, ülkelerarası evliliklerle ilgili yasalar ve düzenlemelerin iyileştirilmesi, yasal tanıtımın güçlendirilmesi ve kitlelerin yasal farkındalığının arttırılmasından geçmektedir. ${ }^{54}$

Çin'in güneybatı sınırında yapılan bu evliliklerden doğan sorunlar doğru şekilde ve zamanında çözülemezse, Çin'in sınır bölgelerindeki sosyal istikrarın, hatta ulusal güvenliğin üzerinde yıkıcı bir etkisi olacaktır. Yazar ise Çin'in sınır bölgelerinde yasadışı evlilikler ile ortaya çıkan sosyal sorunları çözmek için bahsedilen bu araştırmacıların ileri sürdükleri görüş ve önerilerin dışında, birkaç öneride bulunabilmektedir.

\footnotetext{
${ }^{53} \mathrm{He}$, Yuqian和煜乾, “ “Sandaomen” Lilun Shiyuxia de Yunnan Bianjing Diqu Feifa Hunyin Yimin Wenti Yanjiu “三道门”理论视域下的云南边境地区非法 婚姻移民问题研究,” Hubei Jingguan Xueyuan Xuebao 湖北警官学院 学报 30, say1: 4, (2017): 57-62, https://kns.cnki.net/KCMS/detail/detail .aspx ?dbcode $=$ CJFQ\&dbname $=$ CJFDLAST2017\&filename $=$ HBGA201704009\&v $=$ MTM4MzZyV00xRnJDVVI3dWZZdVJ2RnlEa1ZyM09MUy9NYjdHNEg5Yk1xND lGYllSOGVYMUxleFITNORoMVQzcVQ=.

${ }^{54}$ Luo, Wenqing 罗文青, 52-56; Lei, Guangming 雷光明, Wang, Baotong王保同, 72-78; Xie, Shangguo 谢尚果, Luo, Jiayan 罗家珩, 57-64.
}

Üsküdar

Üniversitesi

Sosyal Bilimler

Dergisi, 2021;

sayı: 13 ,

$333-374$ 


\section{Liping HU}

Her şeyden önce, uluslararası evliliklerle ilgili kanun ve yönetmeliklerin iyileştirilmesi temelinde, insan odaklı bir düşünce doğrultusunda, sınırda yabancı uyrukluların evliliklerin yönetimden sorumlu özel teşkilatlar kurulmalı ve ilgili kanuna ve yönetmeliklere göre yabancı uyrukluların evlilik yapmalarına yardım etmelidir. Aynı zamanda, sınır sakinlerinin uluslararası evlilikler yapmalarını kolaylaştırmak için evlilik kayıt prosedürleri basitleştirilmeli ve resmi nikahaya ilişkin ücretlendirme standartları düşürülmelidir. Bunun dışında, Çinli erkeklerle evli olup Çin'dee uzun süredir yaşamakta olan ve Çin vatandaşına geçmek isteyen Vietnamlı kadınlar için, göçmenlik prosedürleri basitleştirilip onlara Çin vatandaşlığı verilmelidir.

Üsküdar

University

Journal of Social

Sciences, 2021; issue: 13 , $333-374$

İkincisi, hukuki, politik ve hümanist yaklaşımı birleştiren bir bakış açısı oluşturarak bu ulus ötesi evlilikten doğmuş ailelere ve bu tür ailelerde yaşayan Vietnamlı kadınlara ve çocuklara daha fazla önem verilmelidir. $\mathrm{Bu}$ süreçte ulus ötesi evlilik içinde bulunan ailelerin ve Vietnamlı kadınların çeşitli yollarla kalkınma gereksinimleri giderilmeli ve yoksulluğun azaltılmasına yönelik çeşitli etkili yöntemler kullanılmalıdır. Özellikle bu tür ailelerin ve Vietnamlı kadınların gelişimini desteklemek için eğitim gelişimi ve topluluk inşasının önemi vurgulanmalıdır. Aynı zamanda, çeşitli örgütsel güçler aracılığıyla bu kadınların ve ailelerinin gelişimi sağlanmalı, mesela, Çin sınırındaki yerel yönetimler ve diğer ilgili sosyal örgütler de uluslararası evlilik içerisindeki ailelerin geçim sıkıntılarının giderilmesi, çocuklarının eğitimi gibi sorunların çözümü için özel hizmetler vermeli ve topluluk çalışması yoluyla önerilerde bulunmalıdırlar.

Son olarak, Çin ve Vietnam sınır bölgelerinde ulus ötesi evliliklerin yönetiminin güçlendirilmesi ve bu tür evliliklerden kaynaklanan sorunların en aza indirilmesi için yasa dışı giriş, yasa dışı ikamet, yasa dışı evlilik dahil olmak üzere yasa dışı faaliyetler için bir değerlendirme ve cezalandırma sistemini oluşturulmalıdır. Örneğin, göçmenlerin yasadışı olarak Çin’e girmelerini ve yerleşmelerini en aza indirgemek için Çin, Çin -Vietnam 


\section{Çin’in Güneybatı Sınırında Yapılan Uluslararası Evliliklerdeki "Vietnamlı Kadın"}

sınır bölgelerindeki göçmenlik yönetimini güçlendirmeli, yasadışı giriş ve çıkış yapanları sıkı bir şekilde yönetmeli ve yasadışı göçmenlere ilgili cezaları ciddi bir biçimde uygulamalıdır. Bu doğrultuda, Çin-Vietnam sınır bölgelerinde ulus ötesi evliliklerle yasadışı veya suç teşkil eden faaliyetlerini kontrol edip, bu ulus ötesi evliliklerle yasadışı eylemleri ve suç oranını azaltabilmektedir. Aynı zamanda, yukarıda belirtilen yasadışı ve suç teşkil eden olaylardan herhangi biri tespit edilirse, yerel Çin otoriteleri onları ciddi bir şekilde cezalandırmalıdır. Bunlar dışında, yasadışı ve suç teşkil eden eylemlerin oluşumunu engellemek için Çin ve Vietnam'ın kamu güvenliği departmanları işbirliğini aktif olarak güçlendirmeli ve bu eylemlerin organizatörlerini ciddi şekilde cezalandırmak için etkili önlemler alabilmelidir.

\section{Sonuç}

Çin-Vietnam sınır bölgelerinde yaşayan sakinlerin birbirleriyle evliliklerinin uzun bir geçmişi vardır ve son yıllarda bu iki ülke arasındaki kültürel alışverişin artması, şehre giden göçmen Çinli kadın işçi sayısının artması, evlilikiçin ödenmesi gereken başlık parasının sürekli yükseltilmesi vekursal toplumda sosyal evlilikçemberiningenişlemesinedenleriyle Çin'in sınır bölgelerindeki cinsiyet oranında dengesizlik artmış ve Vietnamlı kadınlar ile Çinli erkeklerin benzer kültür ve yaşam alışkanlarına sahip olmaları, Vietnamlı kadınları mevcut yaşam koşullarının iyileştirilmesi ile ekonomik çıkar gibi sebeplerden dolayı Çin-Vietnam sınırında ulus ötesi evlilikler giderek daha yaygın hale gelmektedir. Bu nedenle, sınır bölgelerinde evlenebilecek kadın bulamayan çok sayıda Çinli genç erkek evlilik güçlüklerini ulus ötesi evlilik yoluyla çözebilir ve bu haliyle bu türlü ulus ötesi evliliğin evlilik kaynaklarının tamamlayıcılığını gerçekleştirilen bir evlilik biçimi olduğu söylenebilmektedir.

Bununla birlikte sınırda Çinli erkeklerle evlenmiş Vietnamlı kadınların çoğunun ekonomik yoksulluk nedeniyle kendi ülkelerinden 


\section{Liping HU}

kimlik belgelerini alabilmeleri için yüksek ücretler ödeyememelerinden veya prosedürlerin karmaşıklığından veya nasıl başvuru yapılacağını bilmemelerinden dolayı kimlik belgelerini alamamaktadır. Bu yüzden Çinli erkeklerle yasal evlilik yerine sadece bir dügün yaparak fiili evlilik yapmışlardır. Bundan ötürü Vietnamlı kadınların Çin'de yasal ikamet belgeleri ve kimlik belgeleri almaları zordur ve Çin’e yasadışı olarak "vatandaş olmayan kadın” olarak yerleşmektedirler. Zira Vietnamlı kadınların yasadışı evlilikler yapıp Çin’e yasadışı yerleşmeleri, sınır bölgelerinin sosyal düzenine ve kamu güvenliğine bir dizi sorun getirmiştir. $\mathrm{Bu}$ nedenle sınır bölgelerinde sosyal kamu yönetiminin zorluğunu artırmıştır. İyi bir sınır ötesi evlilik mekanizmasının nasıl kurulacağı ve bu tür ulus ötesi evliliklerin neden olduğu sorunların nasıl

Üsküdar University Journal of Social

Sciences, 2021; issue: 13 , $333-374$ çözüleceği, Çin-Vietnam sınırında ulus ötesi evliliklerin meydana geldiği alanlara girip derinlemesine araştırılması, saha araştırmasından ilk elden veri elde edilmesi gerekmekte ve bunun temelinde antropoloji, sosyoloji, uluslararası ilişkiler, siyaset, hukuk gibi birçok disiplinin birleştirilip farklı yönden tartışılması gerekmektedir.

\section{KAYNAKÇA}

Adiloğlu, Selda. "Kosovalı Kadın Göçmenler ve Sosyal Motivasyonları", Uluslararası Toplum Araştırmaları Dergisi, 8, No.15, (2018): 830-857. https://doi.org/10.26466/opus.413256.

Altun, Nurullah ve Dinç, Aybike, "Yabancı Gelinlerin Türk Ailesi İçindeki Yerine Sosyolojik Bir Bakış(pdf.)”, Mart 25-27, Halk Kültüründe Aile Uluslararası Sempozyumu, (2016). https://www.academia. edu/25173459/

Appadurai, Arjun.'Global ethnoscapes: notes and queries for a transnational anthropology', in R. G. Fox (ed.) Recapturing anthropology: 


\section{Çin’in Güneybatı Sınırında Yapılan Uluslararası Evliliklerdeki "Vietnamlı Kadın"}

working in the present, Santa Fe: School of American Research Press, (1991): 191-210, https://eclass.aegean.gr/modules/document/file. php/SA200/Appadurai\%201991.pdf.

Bao, Yueping 保跃平, “Xuanzeyu Kunjing: Yunnan Bianjing Kuaguo Hunyin de Shehuixue Fenxi, 选择与困境: 云南边境跨国婚姻的社 会学分析”, Beifang Minzu Daxue Xuebao (Zhexue Shehui Kexueban)北 方民族大学学报(哲学社会科学版), Say1: 4, (2013): 5-12, https:// kns.cnki.net $/ \mathrm{KCMS} /$ detail/detail.aspx ?dbcode $=\mathrm{CJFQ} \& d$ dbname $=$ CJFD2013\&filename=XBDR201304002\&v=MDE1Njk5TE1xNDlGW m9SOGVYMUx1eFITN0RoMVQzcVRyV00xRnJDVVI3dWZZ dVJ2Rnk3blZyM09QUy9QZkxHNEg=.

Chen, Xun 陈讯, “Ziyuan Hubu, Hunsu Leitong Yu Jiegouxing Liliang Baohuxia de Zhongyue Bianjing Kuaguo Hunyin Yanjiu--Yi Guangxi Chongzuoshi G'cun Weili 资源互补、婚俗类同与结构性力量保护 下的中越边境跨国婚姻研究---以广西崇左市G 村为例”, Yunnan Xingzheng Xueyuan Xuebao云南行政学院学报 19, Say1: 4, (2017): 5-11, https://doi.org/10.16273/j.cnki.53-1134/d.2017.04.001.

Constable, Nicole. Romance on the Global Stage: Virtual Ethnography, Pen Pals and Mail Order Marriages. California: University of California Press, 2003.

Cottrell, Ann Baker. Cross - National Marriages: A Review of the Literature, Journal of Comparative Family Studies 21, No. 2 (Summer 1990): 151-169, https://doi.org/10.3138/jcfs.21.2.151(https://www. jstor.org/stable/41602075)

Dai, Bo ve Zhao, Deguang 戴波, 赵德光, “Zhongmian, Zhonglao, Zhongyue Shaoshu Minzu Kuajing Hunyin Xingwei de Jingjixue Sikao 中缅、中老、中越少数民族跨境婚姻行为的经济学思考”, Shijie Minzu世界民族, Say1: 2, (2016): 54-65, https:// t.cnki.net/kcms/de

Üsküdar Üniversitesi Sosyal Bilimler Dergisi, 2021; sayl: 13 , $333-374$ 


\section{Liping HU}

tail?v=3uoqIhG8C46NmWw7YpEsKMypi3qVj28LntHptynnzpiPCH BHXhEuVbMJRGgNKRVeup5_73WebypxdBAPJQ2yZbNCZD6isJd\&uniplatform $=$ NZKPT

Deniz, Ayla ve Özgür, E. Murat . "Antalya'daki Rus gelinler: Göçten evliliğe, evlilikten göçe”, Sosyoloji Dergisi, 3, No. 27, (2013): 151-175. https://dergipark.org.tr/tr/pub/iusosyoloji/issue/540/5009.

Davin, Delia. Marriage Migration in China and East Asia, Journal of Contemporary China16, No. 50 (2007): 83-95, https://doi. org/10.1080/10670560601026827.

Erkeç, Ulviya Filiyeva. "Evlilik Yoluyla Kadın Göçü ve Türkiye’de "Rus Gelin”lerin Durumu”, Sosyal ve Beşeri Bilimler Dergisi, 1, No. 2, (2017):

Üsküdar University Journal of Social

Sciences, 2021; issue: 13 , 333-374 21- 43. https:// dergipark.org.tr/tr/pub/jssh/issue/35726/393283.

Fang, Tianjian 方天建, “Zhongyue Bianjing Kuajing Minzu Hunyin Diaochayu Fenxi---Yi Yunnansheng Funingxian Tianpengzhen, Muyangzhen Weili 中越边境跨境民族婚姻调查与分析一一以 云南省富宁县田蓬镇、木央镇为例”, Minzu Xuekan民族学刊 6, Sayı: 6 (2015): 55-67, https://kns.cnki.net/KCMS/detail/detail. aspx ?dbcode $=$ CJFQ $\&$ dbname $=$ CJFDLAST2016\&filename $=$ MZXK201 506010\&v=MDc1NTg3TUtEZlRaYkc0SDIUTXFZOUVaSVI4ZVgxT HV4WVM3RGgxVDNxVHJXTTFGckNVUjd1Zll1UnZGeTdnVkw=.

Gökmen, Çisel Ekiz. "Türk Turizminin Yabancı Gelinleri: Marmaris Yöresinde Turizm Sektöründe Çalışan Göçmen Kadınlar”, Çalışma ve Toplum, No. 1, (2011): 201-232. https://www.calismatoplum.org/ Content/pdf/calisma-toplum-1354-d767667b.pdf;

Gu, Jiarong 谷家荣, “Diyu、Shenfen Yu Rentong---Yunnan Jinshuihecun Daizu Kuaguo Hunyin Diaocha地域、身份与认同——云南金水 河村傣族跨国婚姻调查”, Qinghai Minzu Yanjiu青海民族研究 20, Sayı: 4, (Ekim 2009): 5-9, https://kns.cnki.net/KCMS/detail/detail. 
Çin’in Güneybatı Sınırında Yapılan Uluslararası Evliliklerdeki "Vietnamlı Kadın"

aspx ?dbcode $=$ CJFQ $\&$ dbname $=$ CJFD2009 $\&$ filename $=$ QHMJ2009040 04\&v=MzI2MDdTN0RoMVQzcVRyV00xRnJDVVI3dWZZdVJ2Rnk va1dyck5OQ1hHWkxHNEh0ak1xNDIGWUISOGVYMUx1eFk=.

$\mathrm{He}$, Yuqian和煜乾, “ “Sandaomen” Lilun Shiyuxia de Yunnan Bianjing Diqu Feifa Hunyin Yimin Wenti Yanjiu “三道门”理论 视域下的云南边境地区非法婚姻移民问题研究”, Hubei Jingguan Xueyuan Xuebao 湖北警官学院学报 30, Sayı: 4, (2017): 57-62, https://kns.cnki.net/KCMS/detail/detail. aspx ?dbcode $=$ CJFQ $\&$ dbname $=$ CJFDLAST2017\&filename $=$ HBGA20 1704009\&v=MTM4MzZyV00xRnJDVVI3dWZZdVJ2RnlEa1ZyM09 MUy 9 NYjd H N E 5 Yk 1 x N D lGY 11S O GVYMUx 1 e F1T N ORoMVQzcVQ=.

Huang, Liuran黄流然、Li, Juan 李娟、Long, Yao龙耀, “Zhongyue Bianjing Kuaguo Hunyin Wenti de Shehuixue Sikao 中越边境跨国婚 姻问题的社会学思考”, Liaoning Xingzheng Xueyuan Xuebao (Shehui Renwen) 辽宁行政学院学报(社会人文), Say1: 1 (2008): 201-202, https://kns.cnki.net/KCMS/detail/detail.aspx?dbcode=CJFQ\&dbnam e $=$ CJFD2008\&filename $=$ LLXY200801112\&v=MTAxMDg3RGgxVDN xVHJXTTFGckNVUjd1Zll1UnZGeUhrVTd2S0tTSFRkN0c0SHRuT XJvNUVab1I4ZVgxTHV4WVM=.

Huang, Xueyan 黄雪燕, “Zhongyue Bianmin Kuaguo Hunyin Wenti Tanxi---Dui Guangxi Napoxian Bainanxiang Bianmin Yu Yuenan Bianmin Feifa Tonghun de Diaocha中越边民跨国婚姻问题探析---对广西 那坡县百南乡边民与越南边民非法通婚的调查”, Chuangcheng传 承, Say1: 4, (2014) : 106-107, https://doi.org/10.16743/j.cnki.cn45$1357 /$ d.2014.04.042.

Jones, Gavin and Shen, Hsiu-hua, International Marriage İn East And SoutheastAsia:TrendsAndResearchEmphases.CitizenshipStudies12,No.1, (2008, February): 9-25. https://doi.org/10.1080/13621020701794091. 


\section{Liping HU}

Lee, Yean-Ju \& Seol, Dong -Hoon \& Cho, Sung -Nam, International Marriages In South Korea: The Significance of Nationality And Ethnicity, Journal of Population Research 23, No. 2 (2006): 165-182, https://link. springer.com/content/pdf/10.1007/BF03031814.pdf.

Lee, Hye-Kyung. International Marriageand the State in South Korea:Focusingon Governmental Policy, Citizenship Studies 12, No.1 (2008): 107-123. https://doi.org/10.1080/13621020701794240

Lei, Guangming雷光明, Wang, Baotong王保同, “Woguo Bianmin Kuajing Hunyin Jiating de Kunhuo Yu Sikao---Yi Yunnan、Guangxi Bianjing Diqu Weili我国边民跨境婚姻家庭的困境与思考---以云 南、广西边境地区为例”, Zhongyang Minzu Daxue Xuebao(Zhexue

Üsküdar

University

Journal of Social

Sciences, 2021; issue: 13 , 333-374 Shehui Kexueban)中央民族大学学报(哲学社会科学版) 43, Say1: 2, (2016): 72-78, https://doi.org/10.15970/j.cnki.1005-8575.2016.02.010.

Li, Bihua, 李碧华, “Youliyu Shehuizhiwai De Qunti--- Guangxi Tiandengxiang Zhongyue Kuajing Feifa Hunyin Diaocha 游 离于社会之外的群体——广西天等县中越跨境非法 婚姻调查”, Dongnanya Zongheng, 东南亚纵横, Say1: 9, (2008): 60-66, https://kns.cnki.net/KCMS/detail/detail. asp $x$ dbcode $=$ CJFQ $\&$ dbname $=$ CJFD2008 $\&$ filename $=$ DLYZ2008090 14\&v=MTM2OTVFWUISOGVYMUx1eFlTN0RoMVQzcVRyV00x RnJDVVI3dWZZdVJ2RnkvZ1c3N05JU0hTZExHNEh0bk1wbzk=.

Li，Juan李娟，Luo， Liuning罗柳宁,Long，Yao龙耀，“Renleixue Shiyezhong de "Wuguoji Nüren"---Yi Guangxi Daxingxian A'cunWeili 人类学视野中的”无国籍女人”---以广西大新县A村为例”, Baise Xueyuan Xuebao百色学院学报 20, Say1: 1, (2007) :7-14, https://doi. org/10.16726/j.cnki.bsxb.2007.01.002.

Li, Xueyan 李雪岩, Long, Yao 龙耀, “Zhongyue Bianjing Kuaguo Hunyin Wenti Yanjiu (Funüpian) 中越边境跨国婚姻问题研究(妇 
Çin’in Güneybatı Sınırında Yapılan Uluslararası Evliliklerdeki "Vietnamlı Kadın"

女篇）---以广西大新县德天村为例”, Shijie Minzu世界民族, Say1: 4, (2008): 75-80, https://kns.cnki.net/ KCMS/ detail/ detail.aspx? $\mathrm{db}$ code $=$ CJFQ $\&$ dbname $=$ CJFD2008 \& filename $=$ TRIB200804011\&v $=$ MDAwNDFyQ1VSN3VmWXVSdkZ5N2hXcnpQTVQvQ2JMRzRId G5NcTQ5RVpZUjhlWDFMdXhZUzdEaDFUM3FUcldNMUY=.

Liu, Jifeng刘计峰, “Zhongyue Bianjing Kuaguo Hunyin Yanjiu Shuping 中越边境跨国婚姻研究述评”, Xibei Renkou西北人口 32, Say1: 6, (2011): 64-68, https://doi.org/10.15884/j.cnki.issn.10070672.2011.06.018.

Lloyd, Kathryn A. Wives for Sale: The Modern International Mail Order Bride Industry, Northwestern Journal of International Law \& Business 20, No.2 (Winter 2000): 341-368, https://scholarlycommons.law. northwestern.edu/cgi/viewcontent.cgi?article $=1512 \&$ context $=$ njilb.

Lu, Haifa 陆海发, “Bianjing Kuaguo Hunyin Yimin Zhili: Tiaozhanyu Pojie Zhidao边境跨国婚姻移民治理: 挑战与破解之道”, Xinan Minzu Daxue Xuebao(Renwen Shehui Kexueban) 西南民族大学学 报(人文社会科学版), 37, Say1: 3, (2016): 48-53, https://kns.cnki. net $/$ KCMS $/$ detail/detail.aspx?dbcode $=$ CJFQ \& dbname $=$ CJFDLAST 2016\&filename $=$ XNZS201603009\&v=MDQ2OTBmTXJJOUZiWVI4 ZVgxTHV4WVM3RGgxVDNxVHJXTTFGckNVUjd1Zll1UnZGeTdtV UwvTVBTUFJmYkc0SDk=.

Lu, Haifa, 陆海发, “Bianjing Zhilizhong de Kuaguo Hunyin Yimin: Tezheng, Dongli Jiqi Yingxiang --- Jiyudui Yunnan Liangge Biangjingxian e Diaochayu Sikao边境治理中的跨国婚姻移民: 特征、动力及 其影响---基于对云南两个边境县的调查与思考”, Yunnan Minzu Daxue Xuebao(Zhexue Shehui Kexueban)云南民族大学学报 (哲学 社会科学版) 34, Say1: 5, (2017) : 62-70, https://doi.org/10.13727/j. cnki.53-1191/c.2017.05.011. 


\section{Liping HU}

Luo, Liuning 罗柳宁, “Lilun Zhongyue Bianjing Kuaguo Hunyin Jianli de Jichu---Jianlun “Wuguoji Nüren” De Shenfen 例论中越边境跨国婚 姻建立的基础-----兼论“无国籍女人”的身份”, Guangxi Minzu Yanjiu 广西民族研究, Say1: 5, (2010): 57-61, https://kns.cnki.net/KCMS/ detail $/$ detail aspx ?dbcode $=$ CJFQ $\&$ dbname $=C J F D 2010 \&$ filename $=$ MZYA201001015\&v=MjA3NDZ1Zll1UnZGeXptVXI3S0tEZINiN0c0 SDIITXJvOUVZWVI4ZVgxTHV4WVM3RGgxVDNxVHJXTTFGckNVUjc=.

Luo, Liuning罗柳宁, Long, Yao龙耀, “Zhongyue Bianjing Kuaguo Hunyin de Liubian Jiqi Sikao中越边境跨国婚姻的流变及其思考”, Baise Xueyuan Xuebao百色学院学报, 20, Say1: 1, (2007) :15-21, https:// doi.org/10.16726/j.cnki.bsxb.2007.01.003.

Üsküdar

University

Journal of Social

Sciences, 2021; issue: 13 , 333-374

Luo, Wenqing 罗文青, “Heping Yu Jiaowang: Guangxi Bianjing Diqu Kuaguo Hunyin Wenti Chutan 和平与交往: 广西边境地 区跨国婚姻问题初探”, Guangxi Shifan Daxue Xuebao (Zhexue Shehui Kexueban)广西师范大学学报(哲学社会科学版) 42, Sayt: 1, (2006): 52-56, https://kns.cnki.net/KCMS/detail/detail. aspx dbcode $=$ CJFQ \&dbname $=$ CJFD2006\&filename $=$ GXSS2006010 1 3\&v=MTcyNzh6S0lqWFlmYkc0SHRmTXJvOUVaNFI4ZVgxTHV4W VM3RGgxVDNxVHJXTTFGckNVUjd1Zll1UnZGeXpsVjc=.

Luo, Wenqing罗文青, “Yazhou Hunyin Yimin Shijiaoxia de Zhongyue Kuaguo Hunyin Wenti Yanjiu亚洲婚姻移民视角下的中越跨国婚姻 问题研究”, Changjiang Shifan Xueyuan Xuebao长江师范学院学报 29, Say1: 3, (2013): 1-6, https://xuewen.cnki.net/CJFD-FLSZ201303002. html.

Man, Liping 满丽萍, “Yimin Shehuixue Shiyexiao de Dianyue Bianjing Feifa Kuaguo Hunyin Yinmin Wenti移民社会学视野下的滇越边 境非法跨国婚姻移民问题”, Honghe Xueyuan Xuebao 红河学院 学报 10, Say1: 1, (2012): 19-23. https://doi.org/10.13963/j.cnki. hhuxb.2012.01.026. 


\section{Çin’in Güneybatı Sınırında Yapılan Uluslararası Evliliklerdeki "Vietnamlı Kadın"}

Nakipbayeva, Zhanar. Umutların ve Hayal Kırıklikların Sosyo-Kültürel Arka Planı: Türk Erkekleriyle Evlenen Kazakistanlı Kadınların Evlilik Memnuniyeti Üzerine Nitel Bir Çalışma (Yayınlanmamış Doktora Tezi), Ankara: Hacettepe Üniversitesi Sosyal Bilimler Enstitüsü, 2020.

Niedomysl, Thomas \& Östh, John \& Ham, Maarten van. The Globalisation of Marriage Fields: The Swedish Case, Journal of Ethnic and Migration Studies 36, No.7, (2010): 1119-1138, https://doi. org/10.1080/13691830903488184.

Piper, Nicola. International Marriage in Japan: 'Race' and 'Gender' Perspectives, Gender, Place and Culture 4, No. 3 (1997): 321-338, https:// doi.org/10.1080/09663699725378.

Price, C. A. \& Zubrzycki, J. The use of inter-marriage statistics as an index of assimilation, Population Studies 16, No.1 (1962): 58-69, doi:10.1080/0 0324728.1962.10416769

Pusch, Barbara, "Karşı İstikametten Göç: Türkiye'deki Yüksek Vasıflı Alman Kadınlar”, Sosyoloji Dergisi 3, No. 27/2 (2013): 123-149. https:// dergipark.org.tr/tr/pub/iusosyoloji/issue/540/5008.

Rosario, Teresita C.Del. Bridal Diaspora: Migration And Marriage Among Filipino Women, Indian Journal of Gender Studies, No. 12, (2005): 253273. https://doi.org/10.1177/097152150501200205.

Seah, Mabel. 'The Famıly' As An Analytıcal Tool: Cases From International Marriages And Marriage Migration İn East Asia, International Journal Of Sociology Of The Family 38, No. 1 (2012): 63-84, https://www.jstor.org/ stable/43488390?seq=1\#metadata_info_tab_contents.

Shipper, Apichai W.Introduction: Politics of Citizenship and Transnational Gendered Migration in East and Southeast Asia, Pacific Affairs 83, No. 1 (Spring 2010): 11-29, https://dornsife.usc.edu/assets/sites/731/docs/ Politics_of_Citizenship.pdf; 


\section{Liping HU}

So, Alvin Y. Cross-Border Families in Hong Kong: The Role of Social Class and Politics, Critical Asian Studies 35, No.4 (2003): 515-534, https://doi. org/10.1080/1467271032000147014.

Suzuki, Nobue. Inside the Home: Power and Negotiation in Filipina Japanese Marriages, Women's Studies 33, No.4 (2004): 481-506, https:// doi.org/10.1080/00497870490445027.

Tan, Eugene K.B. A union of gender equality and pragmatic patriarchy: internationalmarriages and citizenshiplawsin Singapore, CitizenshipStudies 12, No. 1 (2008): 73-89, https://doi.org/10.1080/13621020701794190.

Tao, Zixiang 陶自祥, “Zhongyue Bianjing Kuaguo Hunyin Chansheng de Shehui Jichu---Yi Guangxi Longzhouxian C'cun Weili 中越边境

Üsküdar

University

Journal of Social

Sciences, 2021; issue: 13 , 333-374 跨国婚姻产生的社会基础--以广西龙州县 G村为例”, Renkou Yu Shehui人口与社会 33, Say1: 3, (2017): 90-103, https://doi. org/10.14132/j.2095-7963.2017.03.011.

Tapales, Proserpina Domingo. Women, Migration, and the MailOrder Bride Phenomenon: Focus on Australia, Philippine Journal of Public Administration 34, No. 4 (1990): 311- 322,https://pssc.org.ph/ wpcontent/psscarchives/Philippine\%20Journal\%20of\%20Public\%20 Administration/1990/Num\%204/07_Women_\%20Migration\%20 and\%20the\%20MailOrder\%20Bride.pdf.

Wang, Binbin 王涁涁, Li, Kaidong李凯冬, “Zhongyue Bianjing Kuaguo Hunyindui Bianjing Cunluo Zhili de Yingxiang---Yi Gejiecun Hanizu Weili 中越边境跨国婚姻对边境村落治理的影响---以隔界村哈尼 族为例," Honghe Xueyuan Xuebao 红河学院学报 15, Say1: 4, (2017): 16-18, https://doi.org/10.13963/j.cnki.hhuxb.2017.04.004.

Wang, Hong-zen. Hidden Spaces of Resistance of the Subordinated: Case Studies from Vietnamese Female Migrant Partners in Taiwan, International Migration Review 41, No. 3 (2007): 706-727, https://doi.org/10.1111/ j.1747-7379.2007.00091.x. 


\section{Çin’in Güneybatı Sınırında Yapılan Uluslararası Evliliklerdeki "Vietnamlı Kadın"}

Wang, Xiaodan王晓丹(a), “Zhongyue Bianjing Kuaguo Hunyinzhong NüxingHunyin QianyideYunayinHeYingxiang中越边境跨国婚姻中女 性婚姻迁移的原因和影响——以云南省文山州为例”, Chuxiong Shifan Xueyuan Xuebao楚雄师范学院学报 26, Say1: 8, (2011): 9195, http://220.191.224.148:9001/KCMS/detail/detail.aspx?filename= CXSZ201108018 \& dbcode $=$ CJFQ \&dbname $=$ CJFD2011.

Wang, Xiaodan 王晓丹(b), “Zhongyue Bianjing Kuaguo Hunyin de Dongji he Shehui Yingxiang---Yi Yunnansheng Malipoxian Weili中越 边境跨国婚姻的动机和社会影响— - 以云南省麻栗坡县为例”, Yunnan Shifan Daxue Xuebao (Zhexue Shehui Kexueban) 云南师范大学 学报(哲学社会科学版) 43, No. 1, (2011): 117-120. https:// t.cnki. net/kcms/detail?v=3uoqIhG8C46NmWw7YpEsKLWhGHP2RH Esf UP 6 uy pmiObOkRm QOtSO 0 tj 4 N oqTL 6 Uzk 5 q 0 qZ_ ipv9AJUgZ9GGS9ZPH-3L6Mz\&uniplatform=NZKPT.

Wu, Xingzhi 吴兴帜, “Zhongyue Kuajing Minzu Jiaowang yu Bianmin Shehui Zhili Yanjiu --- Yi Yunnansheng Hekou, Jinpingxian Weili 中越跨 境民族交往与边民社会治理研究——以云南省河口、金平县为 例”, Qinghai Shifan Daxue Xuebao (Zhexue Shhui Kexueban)青海师范 大学学报(哲学社会科学版) 37, Say1: 2, (2015): 50-55, https://doi. org/10.16229/j.cnki.issn1000-5102.2015.02.011.

Xie, Shangguo 谢尚果, Luo, jiayan罗家行, “Zhongyue Bianjing Diqu Kuaguo Hunyin Zhili Mushi Fenxi 中越边境地区跨国 婚姻治理模式分析”, Guangxi Minzu Yanjiu 广西民族研究, Say1: 2 (2016): 57-64, https://kns.cnki.net/KCMS/detail/detail. asp ? dbcode $=$ CJFQ $\&$ dbname $=$ CJFDLAST2016\&filename $=$ MZYA20 1602010\&v=MTQwNDRiN0c0SDlmTXJZOUVaSVI4ZVgxTHV4WV M3RGgxVDNxVHJXTTFGckNVUjd1Zll1UnZGeUhtVXIvTktEZIM=.

Yıldırım, Ayşe, "Sınır-ötesi Evliliklerve Sınır Çokkarılılığı: “İthal Kumalar”", Antropoloji, No. 29, (2015): 131-162. https://doi.org/10.1501/ antro_0000000315. 


\section{Liping HU}

Zhou, Jianxin 周建新, “Zhongyue Bianjing Kuaguo Hunyinzhong Nüxing Jiqi Zinü de Shenfen Kunjing---YiGuangxi Daxinxian Zhuangcun Gean Weili 中越边境跨国婚姻中女性及其子女的身份困境—— 以广西大新县壮村个案为例”, Sixiang Zhanxian思想战线, Say1: 4, (2008): 1-8, https://kns.cnki.net/KCMS/detail/detail.aspx?dbcode= CJFQ\&dbname $=$ CJFD2008\&filename $=$ SXZX200804003\&v $=$ MzI0ND dmWXVSdkZ5SGxWN3JJTmpYUmRyRzRIdG5NcTQ5Rlo0UjhlWDF MdXhZUzdEaDFUM3FUcldNMUZyQ1VSN3U=.

Üsküdar

University

Journal

of Social

Sciences, 2021;

issue: 13 ,

333-374 